\title{
Borrowed Color and Flora/Fauna Terminology in Northwest New Guinea
}

\author{
Emily Gasser \\ Department of Linguistics, Swarthmore College, USA \\ egasserı@swarthmore.edu
}

\begin{abstract}
The northwestern part of the island of New Guinea has been the site of intense contact between a hugely diverse set of languages. Languages from at least nine nonAustronesian families (plus several isolates) are spoken alongside Austronesian languages from the South Halmahera-West New Guinea branch, which arrived in the region roughly 3500 years ago. This paper looks at lexical items in the semantic areas of flora, fauna, and color terms and catalogues apparent loans between $5^{2}$ of these languages, some relatively widespread ('crocodile', 'chicken', 'dog') and some much more limited in their scope. So far as the direction of borrowing can be established, the patterns of shared forms indicate ongoing lexical transfer across the region with a strong preference for Austronesian-to-Papuan borrowing, suggesting a historical pattern of Austronesian cultural influence in the region.
\end{abstract}

\section{Keywords}

flora - fauna - Wanderwörter - loanwords - Austronesian - Papuan languages

Northwest New Guinea, comprising Indonesia's West Papua and Papua provinces from the Raja Ampat Islands to the Mamberamo River delta, has been the site of intense contact between a hugely diverse set of languages. Languages from at least nine unrelated families, plus several isolates, are spoken alongside Austronesian languages from the South Halmahera-West New Guinea

(C) EMILY GASSER, 2020 | DOI:10.1163/19552629-01203003

This is an open access article distributed under the terms of the prevailing CC-BY-NC License at the time of publication. 
(SHWNG) branch, which arrived in the region roughly 3500 years ago. Rich coastal trade networks, alongside other social interactions, have resulted in long-term contact, which has left a visible mark on the languages in question (Klamer, 2002; Foley, 2010; Schapper, 2017; Reesink and Dunn, 2018; Schapper, 2018; inter alia).

This paper looks particularly language contact in the semantic fields of color terminology, animals, insects, and mostly edible plants in both Austronesian (AN) and non-Austronesian ${ }^{1}$ (collectively 'Papuan'; PAP) languages spoken in the westernmost third of the island of New Guinea, and gives a descriptive overview of patterns of cross- and intra-family borrowings within this lexical domain. A main finding is that the majority of loans whose source can be identified have moved from Austronesian into Papuan languages, suggesting that the Austronesians, relative newcomers in the region, have historically been an influential group.

Previous work has discussed lexical connections between Papuan and Austronesian languages in the region, though none have focused specifically on this semantic field. McElhanon and Voorhoeve (1970) discuss nine possible AN loans into Papuan lexicons from a list of 53 possible cognates shared across Trans-New Guinea languages, including the words for 'leaf', 'star', and 'dog'. Lynch (1981) looks at the same 53 items and expands the number of possible AN loans to 22. Lynch identifies an additional 21 items based on wordlists from Franklin's (1975) work on Proto-Engan, and reproduces an additional four potential loans pointed out by Wurm, Voorhoeve, and McElhanon (1975) in TransNew Guinea. Lynch's examples span a number of of semantic fields. They also vary in plausibility. On one end of the spectrum are fairly solid cases like Awyu rõ, õ, ron 'leaf' from Proto-Malayo-Polynesian (PMP) *dahun², reflected in many Cenderawasih Bay languages as raun (Wooi), ram (Biak), rànu (Moor), or similar forms. This contrasts for example with the word for 'pandanus', which surfaces in Franklin's (Papuan) E3 group as aga, ank, ankce, anga and is linked by Lynch to Proto-Oceanic *kiekie ${ }^{3}$, which seems rather more of a long shot. More recently, Reesink (1999b) describes both lexical and morpho-syntactic features apparently shared between the Papuan and Austronesian languages

1 I use the terms 'Papuan' and 'non-Austronesian' interchangeably in this paper, though of course all of the languages discussed here are spoken in Papua and are therefore 'Papuan' in one sense of the word. These are cover terms for all of the languages and families spoken in Melanesia which do not belong to Austronesian, and do not imply relatedness.

2 Lynch gives this as PAN *da[]un, which does not appear in the Austronesian Comparative Dictionary (Blust and Trussel, 2010).

3 This is likely equivalent to *kiRe-kiRe 'pandanus species'. 
of the Bird's Head to make an argument for characterizing this area as a Sprachbund of mixed languages. His examples are generally on stronger footing than Lynch's, but his focus is on the grammatical features. Gasser $(2017 \mathrm{~b})$ considers both lexical and grammatical evidence in examining language contact on Yapen Island. In this paper, I try to be relatively strict in requiring strong resemblance in both form and meaning to increase the chances of an actual loan relationship, though of course chance similarity is always a possibility for any given lexeme. Still, even if some of these should prove to be independent innovations, their quantity is such that the trends discussed here still hold.

In Section 2 I give an overview of the 52 languages surveyed here, data sources, and the lexemes considered. Section 3 discusses the available evidence for dating the introduction of the items discussed here into New Guinea, and their prior familiarity to the Austronesians. Section 4 presents my findings, with Wanderwörter and other widespread loans discussed in Section 4.1, the exceptional case of 'dog' in Section 4.2, and more restricted borrowings in Section 4.3. Unusual word distributions within Austronesian are in Section 4.4. Section 4.5 compares the results of this study to those of the WOLD project (Haspelmath and Tadmor, 2009), and Section 4.6 discusses possible contact scenarios. Section 5 concludes.

\section{Languages and Lexemes}

The sample includes 29 Papuan varieties and 24 Austronesian ones, plus four reconstructed proto-languages for comparison. 'Varieties' here constitutes something between a dialect and a language. Where the same language name was used by multiple authors I have conflated their data, but where different names were used they are considered separately. This sidesteps the issue of whether two varieties are dialects of the same language or different languages, as with Hatam and Mansim, or Manikion and Sougb. In the latter case both varieties are marked on the same geographical span in the map in Fig. 1, as no source could be found from which to construct a boundary. The languages used in this sample are nowhere near an exhaustive accounting of all those spoken in the area, particularly for non-Austronesian varieties. They have been chosen for geographic and genetic breadth and availability of data. Occasional data points outside this set will be cited as they arise; no attempt has been made to compile full wordlists for these additional languages and they are not noted on the map.

The main languages cited here and the sources consulted for each are as follows, arranged by geographic area. The label number for each language on the 


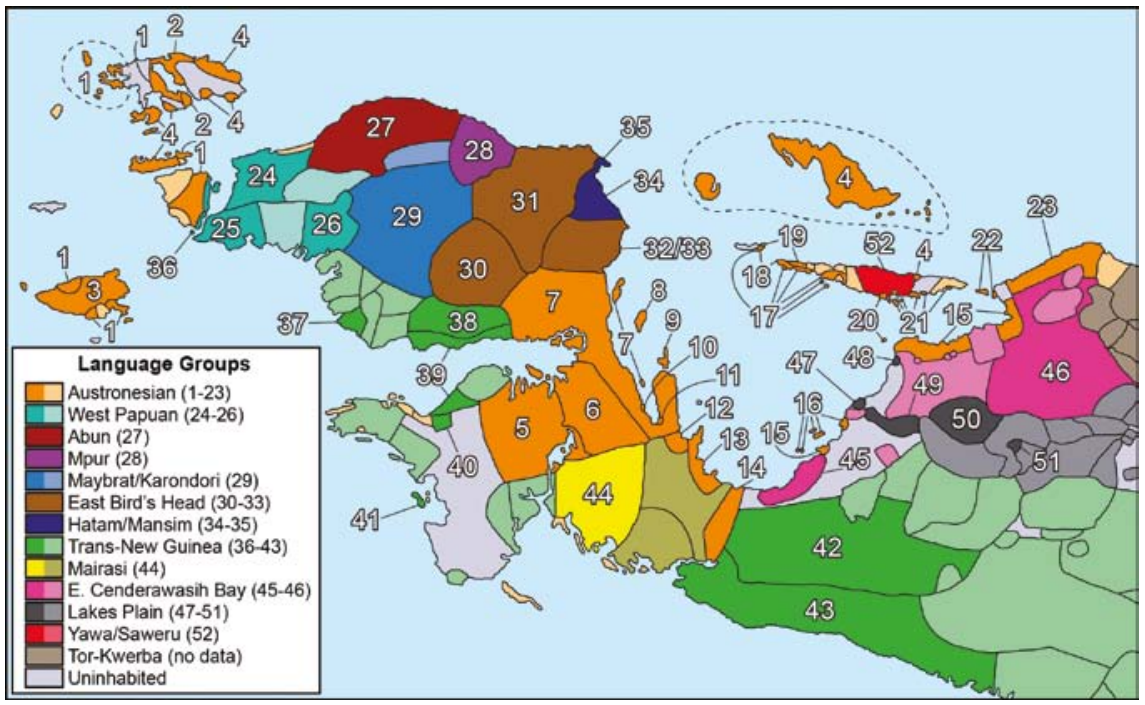

MAP 1 Map of the languages used here.

Adapted from an unpublished siL map, Voorhoeve (1982), Remijsen (2001), Kamholz (2014), the Ethnologue (Lewis, Simons, and Fennig, 2016), Holton (2017), Sawaki (2017), and Arnold (2018). Where two colors are given in the legend for a given family, the color on the left indicates languages included in this sample; that on the right indicates languages with no data. See the language list in the text for the variety corresponding to each label number; languages not included in this sample are unlabeled.

map in Fig. 1 is also given here; languages are labeled on the map first by family, then geography.

\section{- Within Austronesian:}

Proto languages: Proto-Malayo-Polynesian (PMP) and Proto-CentralEastern Malayo-Polynesian (PCEMP): Blust (1993; 1999), Blust and Trussel (2010). Raja Ampat: Ma'ya: Remijsen (2001), van der Leeden (n.d.), map \#1; Ambel: Remijsen (2001); Laura Arnold (2018; p.c.), map \#2; Matbat: Remijsen (2001; 2015), map \#3; Biak: van Hasselt and van Hasselt (1947), van den Heuvel (2006), Than et al. (2011), Gasser (2018), Xavier Bach (p.c.), map \#4. Bomberai and coastal Cenderawasih Bay:

4 The items in these lists differ chiefly in the number and quality of vowels, with Jackson allowing complex clusters that Matsumura often breaks up with a schwa or other vowel. Jackson reports that consecutive identical consonants, such as the initial $k s$ in kkor 'chicken', are individually released, and that voiced stops are prenasalized, which is not reflected in the orthography. 
Irarutu: Matsumura (1991), Jackson (2014), ${ }^{4}$ map \#5; Kuri: author's fieldwork (2011), map \#6; Wamesa: Henning et al. (1991), Gasser (2015), author's fieldwork (2011-2019), map \#7; Meoswar: Anceaux (1992), Xavier Bach (p.c.), map \# 8; Roon: Gasser and Gil (2016), David Gil (p.c.), map \# 9; Dusner: Dalrymple and Mofu (2012; n.d.), Nenepat (2012), map \#10; Tandia: Anceaux (1992), map \#11; Umar: Kamholz (n.d.), map \#12; Yaur: Kamholz (n.d.), map \#13; Yerisiam: Kamholz (n.d.), map \#14; Waropen: Held (1942), map \#15; Moor: Kamholz (n.d.), map \#16. Biak and Yapen Islands and satellites: Biak: map \#4; Ansus: Gasser (2017a), Donohue et al. (n.d.), map \#17; Wooi: Anceaux (1992), Sawaki (2017), Emma Remy (p.c.), author's fieldwork (2011), map \#18; Pom: Gasser (2016), map \#19; Serui Laut: Slump (1924-38), map \#20; Ambai: Grace (1955-56), Silzer (1983), map \#21; Kurudu: Xavier Bach (p.c.), map \#22. Mamberamo delta: Warembori: Donohue (1999), map \#23.

- Non-Austronesian:.

Proto languages: Proto-Lakes Plain (Clouse, 1997); Proto-Trans New Guinea (Pawley, 2005; Ross, 2014). Raja Ampat and Bird's Head proper: Moi: Voorhoeve (1975), Stokhof and Flassy (1985), Menick (1996; 2000), Reesink (1999b), The Rosetta Project (n.d.), map \#24; Seget: Voorhoeve (1975), map \#25; Tehit: Stokhof and Flassy (1985), Reesink (1999b), Hesse (2000), map \#26; Abun: Reesink (1999b), Berry and Berry (1999; 2000), map \#27; Mpur: Miedema and Welling (1985), Reesink (2002c), Odé (2002; 2004), Wabia and Gasser (2019), map \#28; Maybrat: Reesink (1999b), Dol (2007), map \#29; Moskona: Voorhoeve (1975), The Rosetta Project (n.d.), map \#30; Meyah: Voorhoeve (1975), Gravelle (2000; 2002), Reesink (2002c), The Rosetta Project (n.d.), map \#31; Manikion: Voorhoeve (1975), The Rosetta Project (n.d.), map \#32; Sougb: Reesink (1999b; 200ob; 2002a; 2002c), map \#33; Hatam: Donohue (1997), Reesink (1999b; 2000a; 2002c), map \#34; Mansim: Reesink (2002b), map \#35; Duriankere: Voorhoeve (1975), map \#36. South Bird's Head and Bomberai: Inanwatan: de Vries (1996; 2000; 2002; 2004), map \# 37; Arandai: Voorhoeve (1975; 1985), Reesink (1999b), The Rosetta Project (n.d.), map \#38; Kemberano: Voorhoeve (1975), The Rosetta Project (n.d.), map \#39; Mor: Voorhoeve (1975), The Rosetta Project (n.d.), map \#40; Kalamang: Visser (2016), map \#41. Bird's Neck: Ekari: Voorhoeve (1975), The Rosetta Project (n.d.), map \# 42; Kamoro: McElhanon and Voorhoeve (1970), Voorhoeve (1975), The Rosetta Project (n.d.), map \#43; Mairasi: Voorhoeve (1975), The Rosetta Project (n.d.), map \#44; Tunggare: Voorhoeve (1975), The Rosetta Project (n.d.), map \#45. Lakes Plain and Mamberamo: Bauzi: D. Briley (1976), J. Briley 
(1976), Clouse (1997), map \#46; Awera: Clouse (1997), map \# 47; Rasawa: Clouse (1997), map \#48; Tause Deirate: Clouse (1997), map \#49; Tause Weirate: Clouse and Clouse (1993), Clouse (1997), map \#50; Tause Clouse and Clouse (1993), Clouse (1997), map \#51. Yapen Island: Yawa: L. Jones (1986b), Jones, Paai, and Paai (1989), Voorhoeve (1975), author's fieldwork (2016), The Rosetta Project (n.d.), map \#52.

All of the Austronesian languages considered here belong to the South Halmahera-West New Guinea branch of Austronesian, with the likely exceptions of Irarutu and Kuri, spoken on and around the Bomberai peninsula (Jackson, 2014). This paper focuses on the West New Guinea (WNG) portion of SHWNG: those languages spoken on the Bird's Head Peninsula, along the north coast of New Guinea as far east as the Mamberamo River, and on Biak, Yapen, and other minor islands in Cenderawasih Bay, as well as the Raja Ampat islands, ${ }^{5}$ to the exclusion of the South Halmahera languages to the west. While the internal structure of SHWNG has yet to be worked out in detail, some geographic and lower-level genetic groupings can be sketched here; for subgrouping evidence see Kamholz (2014) and the references therein. Ma'ya, Ambel, and Matbat belong to the Raja Ampat-South Halmahera branch of SHWNG. All three are tonal; tones here are represented either by superscript numerals or diacritics according to each language's convention. The Yapen languages, represented here by Ambai, Ansus, Pom, Kurudu, Serui-Laut, Wamesa and Wooi, are spoken on Yapen Island. The one exception is Wamesa, ${ }^{6}$ with three main dialects on the south-western coast of Cenderawasih Bay. The Biakic languages, Yapen's closest relatives, are Biak, Meoswar, Roon, and Dusner, spoken on Biak and Numfor Islands in Cenderawasih Bay and on smaller islands along the coast adjacent to Wamesa territory; Biak has additional communities in Raja Ampat. Kamholz (2014) groups Yaur, Umar, and Yerisiam, spoken along the coast just south of Wamesa, together into a cluster which is sister to Biakic and Yapen. No further groupings can be established. Kuri is located just inland of Wamesa to the south of Bintuni Bay. Wamesa speakers consider Kuri to be part of Wamesa, though it is very clearly a different language despite significant lexical overlap; based on lexical and morphological observations, it is either a dialect of Irarutu or else a close relative. The remaining languages are scattered up the coastline as far as Warembori near the mouth of the Mamberamo River, interspersed

5 The Raja Ampat languages are however more closely related to their South Halmahara cousins than those varieties spoken on mainland New Guinea.

6 Wamesa [wad] is often referred to as Wandamen in the literature; see Gasser (2014) for discussion. 
with Papuan languages along the way. I refer to the languages spoken within and along Cenderawasih Bay as the Cenderawasih Bay (CB) languages, a geographical rather than genetic grouping. Within CB, Moor, Yaur, and Yerisiam are tonal, marked in the orthorgaphy by diacritics.

The Papuan languages included in this sample are far more genetically diverse, though genetic relationships are far from settled here as well (see i.e. discussion within Palmer 2018). Where not otherwise cited, genetic affiliations given here come from the Ethnologue (Lewis, Simons, and Fennig, 2016) and the TransNewGuinea.org database (Greenhill n.d.). Sources disagree on whether Yawa, one of the two non-Austronesian languages spoken on Yapen Island, is an isolate (L. Jones, 1986a) or a member of the West Bird's Head branch of the West Papuan family alongside Moi, Tehit, and Seget (Lewis, Simons, and Fennig, 2016; Greenhill n.d.; Hesse, 200o). Abun is classified by Lewis, Simons, and Fennig (2016) as an isolate, but by Berry and Berry (1999) as another member of the West Papuan phylum. Mpur is also an isolate (Odé, 2002), while Hatam and closely related Mansim (aka Borai) form their own small group (Reesink, 2002 b), though Reesink (1999a; Reesink, 2002c) proposes a distant genetic relationship between these three varieties and the East Bird's Head languages Meyah, Moskona, Manikion, and its dialect Sougb (Voorhoeve, 1975; Reesink, 1996; Gravelle and Gravelle, 1999) - on the basis of shared morphological and syntactic features. The expansive Trans-New Guinea (TNG) family, if we accept its coherence, ${ }^{7}$ is represented here by Ekari (Mei), Kamoro, Arandai, Duriankere, Inanwatan (Suabo), Kemberano, Kalamang (Karas), and Mor, covering (potentially) five of its branches. Tunggare and Bauzi belong to the East Cenderawasih Bay phylum, and Mairasi is the sole representative of the Mairasi family included here. The Lakes Plain family is represented by Awera and Rasawa on the Cenderawasih Bay coast and, progressively farther inland, by Tause Weirate, Tause Deirate, and Tause. Finally, Maybrat is an isolate on the Bird's Head (Reesink, 1996), with perhaps one extant relative.

The word list used for this study includes 70 lexical meanings drawn from the semantic fields of colors ('black', 'red', 'dark', 'light', etc.'), animals ('cassowary', 'pig', 'fish'), insects ('wasp/bee', 'cockroach', 'beetle'), and plants, focusing particularly but not exclusively on edible varieties and plant parts ('sago', 'coconut', 'betel/areca nut', 'root'). This is a sample of convenience, based largely on wordlists used in a lexical survey of Cenderawasih Bay languages I conducted in the summer of 2016, and certainly not exhaustive of all possible or even all salient members of these classes. For the full wordlist, see Appendix II.

7 c.f. Pawley (2005); Ross (2005). 
Despite the ad hoc nature of the list, this is a productive semantic area in which to survey loan patterns. While Bowern et al. (2011) find that $5 \%$ of basic vocabulary terms in their sample of 122 hunter-gatherer and small-scale cultivator languages of Australia, North America, and Amazonia are borrowed, Bowern et al. (2014), expanding that sample to 130 languages, find that flora/ fauna terms are borrowed at nearly twice that rate ( $9.8 \%$ of items). Haynie et al. (2014), drawing from an expanded sample of 135 languages from the same areas, find that within their Australian case study, only $3.4 \%$ of basic vocabulary items fall within their 'highly loaned' category, while $7.7 \%$ of flora/fauna terms and $13.7 \%$ of material culture terms do so, though the pattern is less striking when all three geographic areas are considered. More broadly, they find that acculturation terms (those denoting items rapidly introduced by colonial contact, 'rice' being perhaps the best example in the present study) and those with ritual or other cultural significance are likely to be highly loaned, and that those Wanderwörter which do not fall into these categories are often flora/fauna terms. This semantic field should therefore be a fruitful one for loan items, a prediction which is well borne out by the data.

Ideally, a survey of this type would look at much more specific, perhaps species-level terms, rather than the generic forms used here, collecting 'nipa palm' and 'ironwood' for 'tree', specific varieties of cuscus and sea turtles, etc. This is simply a function of the data available. Where some fieldworkers, such as Stokhof and Flassy (1985), are extremely precise in defining the referents of each term, much more common are shorter and less detailed wordlists, where a single word is given for, say, 'lizard', and it is impossible to know whether this refers to a small house lizard (Indonesian cicak), a larger goanna or monitor lizard, something in between, or the generic term. Flying foxes and other bats are generally not distinguished, nor are the various types of arboreal marsupials, where any subset of 'tree kangaroo', 'kangaroo', 'wallaby', 'cuscus', 'phalanger', or even simply 'tree-dwelling marsupial' may appear, with unclear referent. A great deal more biologically savvy fieldwork is necessary before anything more than the sort of preliminary survey presented here is possible.

Even when these sorts of distinctions can be teased apart, not all words on this list are attested in all languages, so statements to the effect of 'languages $\mathrm{X}$ and Y have form Z' should not be taken to mean that other languages do not have form $\mathrm{Z}$ unless explicitly stated as such, since many forms are unknown. Voorhoeve (1975), for example, covers a great number of individual languages, but only presents 40 lexical items for each, leaving significant gaps. In all, just over half of the cells in a languages-by-items table are filled with at least one attested word, though some have multiple synonyms or closely related forms 
(i.e. multiple species of taro, etc.). Orthographic representations from the sources have generally been maintained; 8 these may hew more or less closely to a phonemic representation, and the phonetic value of a given symbol may vary language to language. I follow Haynie et al. (2014) in using a \% sign to denote forms which are a generalization across the realization of a given borrowed form in a number of languages and stand in for that set as a whole, for example \%kokor to refer to the set of words meaning 'chicken', including Wamesa kokori, Moor kokó, Meyah mongkukar, Arandai kokoro, etc. (see Section 4.1). This is not a reconstruction, as the forms are explicitly borrowed rather than inherited, but can be considered analogous.

\section{3}

\section{Dating Flora/Fauna in New Guinea}

It can be informative in a study such as this to try to date the transmission of loan words by reference to the time of introduction of the items they refer to. Unfortunately this is difficult to do in the Papuan context. While a number of archaeological digs gave been carried out in Papua New Guinea and nearby archipelagos to the east (c.f. Sutton et al. 2009), very limited archaeological work has been done in western (Indonesian) New Guinea or the islands directly to the west which would enable us to identify the pre-historic presence of non-native flora and fauna species (Spriggs, 1995; Pasveer, Clarke and Miller, 2002; White, 2004). Indigenous groups do not have writing traditions, and while European explorers made occasional landfall in Papua beginning in the 16th century (Spriggs, 1998) in conjunction with the spice trade - for example Miguel Roxo de Brito in the early 1580 - the Dutch did not claim colonial sovereignty until 1828. Even then they had very little presence there for the next 60 years, especially outside of major cities (McGibbon, 2004). One result is that written records are of little help in documenting even more recent introductions. This is not to say that New Guinea was isolated from the rest of the world, however. Threads from biology, archaeology, and linguistics support the idea that New Guinea was well-connected via maritime trade routes to Island Southeast Asia and Melanesia well before settlement by the Austronesians 3500 years ago (Denham, 2004; 2010). More recently, the Bird's Head was part of a major trade route for metal, spices, ceramics, and Birds of Paradise reaching through Mainland Southeast Asia as far as India and China starting around 200 BC (Veth, Spriggs, Jatmiko and O'Connor, 1998; Spriggs, 1998). There is additional evidence that people were intentionally moving various species between

8 One exception is the $<$ oe $>$ in Moi data, which here has been changed to $<\mathrm{u}>$. 
Sulawesi, the Moluccas, New Guinea, the Bismark Archipelago and the Solomon Islands as long as 20,00o years ago (White, 2004).

It seems clear from the available linguistic, archaeological, and genetic evidence that both Austronesian and Papuan speakers would have encountered taro (Colocasia esculenta), yams (Dioscorea spp.), and bananas (Musa spp.) prior to Austronesian settlement on New Guinea. All three appear to have been domesticated in New Guinea, probably by 6500 YвP (Lebot, 1999; Denham, 2004, 2010; Fuller et al., 2011). Bananas spread outwards from there, while yams and taro are likely to have been domesticated separately in Southeast Asia; wild variants of all three exist throughout the region ${ }^{9}$ (Matthews, 1995; Lebot, 1999; Kennedy, 2008). Words for 'taro' and 'banana' have been reconstructed to Proto-Austronesian (PAN), spoken on Taiwan roughly 6000 YвP, and 'yam' has been reconstructed back as far as Proto-Malayo-Polynesian (Blust and Trussel, 2010), spoken by the group of Austronesians who first moved from Taiwan to the Philippines about 4500 Y вP. Sago (Metroxylon sagu), breadfruit (Artocarpus altilis), and fruiting pandanus were also New Guinea domesticates (Lebot, 1999; Denham, 2004) with PMP reconstructions (Blust and Trussel 2010). Coconut palms (Cocos nucifera) similarly were likely established throughout the region even before the arrival of the first humans on Sahul 35,000 YBP, and so would have been familiar to all involved (Lebot, 1999); casuarina trees (Casuarina equisetifolia) are similarly widespread (Wilson and Johnson, 2015); terms for both are reconstructable to at least PMP (Blust and Trussel, 2010).

Areca nut (Areca catechu) may have originated in the Philippines; while the betel pepper (Piper betle) chewed with it in the betel quid has been tentatively assigned a Javanese origin (Zumbroich, 2008). Terms for areca and betel pepper have been reconstructed to PAN (Blust and Trussel, 2010), suggesting longterm Austronesian familiarity. Its association with the Lapita culture is weaker than that of the domesticates discussed above, though Lichtenberk (1998) concludes that speakers of Proto-Oceanic did chew betel. Areca remains on Timor have been dated to 4000 ҮвР, but no archaeological evidence exists to date its introduction into New Guinea (Glover, 1979; Zumbroich, 2008).

On the fauna side, fruit bats, Rattus mordax and Rattus praetor are all dated to the Pleistocene era in New Ireland and likely predated human arrival; they and various other murine rodents would have been well known to both Papuans and Austronesians on the Bird's Head well before Austronesian settlement, though Rattus exulans likely accompanied the new Austronesian arrivals

9 Sweet potatoes, however, are a much more recent introduction from South America, arriving in the last 500 years (Golson and Hughes, 1980; Bellwood, 1998). 
(Roberts, 1991; White, 2004; Rowe et al., 2008). Austronesian reconstructions confirm this (Blust and Trussel, 2010). Though not all of these are reconstructed by Blust to PAN, crocodiles, cockatoos, turtles, frogs, snakes, and various hornbill and lizard types would have been present across Island Southeast Asia and New Guinea pre-settlement, while various species of cuscus ${ }^{10}$ (Strigocuscus and Phalanger spp.) can be found from New Guinea west to Sulawesi (Heinsohn, 2002; Schapper, 2011; Gonzalez et al., 2013). Birds of paradise are endemic to New Guinea and the surrounding islands (Raja Ampat, Aru, also eastern Australia), with the exception of Lycocorax pyrrhopterus and Semioptera wallacii in the Moluccas, though these appear quite different than the Paradisaea species most salient around Cenderawasih Bay and the Bird's Head (Michaux, 1994).

Other than murines and fruit bats, the only other mammals native to the Sahul are non-placentals, primarily marsupials such as cuscus, bandicoots, wallabies, tree kangaroos, dasyurids, and thylacines (Rowe et al., 2008). The exact distribution of these pre- 3500 YBP is uncertain. According to Heinsohn (2002), several macropod species may have been introduced to Halmahera and the Kai (Kei) Islands in prehistoric times, but that leaves a wide band of possibility for exactly when translocation occurred and whether Austronesians would have encountered them there. Similarly the Double-Wattled Cassowary (Casuarius casuarius) may have been introduced to Seram from New Guinea in "prehistoric or protohistoric times" (Heinsohn 2002: 362); cassowary eggshells in Toé cave in the Bird's Head have been dated to at least 20,000 Үв (Pasveer et al., 2002).

More controversial are dates for the introduction of pigs, dogs, chickens, and the areca/betel complex into New Guinea from Island Southeast Asia. Farther east, pigs, dogs, and chickens were hallmarks of the Lapita cultural complex, spreading across the Pacific with Austronesian speakers (Spriggs, 1995; Bellwood, 1998; Matisoo-Smith, 2009). While all three were domesticated by the Austronesians, with terms reconstructable to PAN (Blust, 2002; Blust and Trussel, 2010), how and when they entered Northwest New Guinea is less clear. Matisoo-Smith (2009) dates the first introduction of dogs, the forebears to dingoes and New Guinea singing dogs, into the Sahul to between 3500 and 6000 YBP, either accompanying Austronesian settlers or significantly preceding them. Two archaeological sites in the highlands produced dog bones dated to less than 5400 and less than 4500 YвP, but how much less is not specified (Sutton et al., 2009).

10 The Proto-Central-Eastern Malayo-Polynesian reconstructions of cuscus and bandicoot terms are controversial; see Blust (2002; 2012) and Schapper (2011). 
Sutton et al. further claim that there is good reason to believe that dogs and pigs (Sus scrofa) entered New Guinea together, but here the archaeological record is even more mixed. Finds of pig bones in New Guinea have been dated back as far as 12,00о Үв (Golson and Hughes, 1980; Gorecki, Mabin and Campbell, 1991; Sutton et al., 2009), but more recent work has called these dates into question and suggested a date of introduction contemporaneous with Austronesian settlement (Lilley, 1998; Larson et al., 2007; Sutton et al., 2009; Piper, 2017). Either way, pigs appear to have moved to New Guinea under human agency as husbanded animals, ultimately from a Southeast Asian source (Golson and Hughes, 1980; Larson et al., 2007; Dobney, Cucchi and Larson, 2008).

The evidence is much scarcer for chickens in New Guinea. Chicken remains are rare in Island Southeast Asia and Near Oceania archaeological sites (Bellwood, 2007; Storey et al., 2012; Piper, 2017). Only three of 33 archaeological sites in Papua New Guinea, and none in the Bird's Head, report finding chicken bones, and none of these findings can be securely dated to prehistoric times, making their date of arrival impossible to pinpoint (Pasveer et al., 2002; Storey, Ladefoged and Matisoo-Smith, 2008). Chicken remains dated to 3500 чвр were found in the Mussau Islands to the northeast of New Guinea, implying that they must have passed through mainland New Guinea prior to that (Piper, 2017).

More recent introductions into New Guinea from Island Southeast Asia include rice, cassava, other fruits and vegetables, and the common house lizard, or cicak. While early Austronesians cultivated rice, they appear to have moved away from their reliance on the crop and towards heavier use of tubers and fruits as they moved closer to the equator and to New Guinea (Bellwood 1995). Nevertheless, the Portuguese explorer Miguel Roxo de Brito describes seeing rice cultivation on his expeditions to Raja Ampat and MacCluer Gulf in the 1580s (Spriggs, 1998). Cassava (Manihot esculenta) was a post-Colombian introduction from the Americas (Denham, 2010), as was the chili pepper (Capsicum annuum) (Kraft et al., 2014). Heinsohn (2002) posits the house lizard (Hemidactylus frenatus) as a modern stowaway on cargo ships. Housecats are likely also a fairly recent arrival.

\section{Findings and Observations}

\subsection{Chicken, Crocodile, and Other Widespread Words}

The two most widely distributed Wanderwörter ${ }^{11}$ in the sample are the words for 'crocodile' and 'chicken'. (See Maps 2 and 3.) Reesink (1999b) notes both of

11 I use definition of Wanderwörter as forms borrowed repeatedly and widely across a given area, whether or not the source language is identifiable (pace Campbell and Mixco 2007). 
these, and in his, 1999 Hatam grammar he posits a Biakic origin for 'crocodile' (as well as 'rice', discussed further below). While it is true that Biak has been widely used as a language of trade throughout the area, the wide distribution of these words across the Bird's Head and Cenderawasih Bay makes their ultimate origins difficult to pinpoint. I would classify Biak as a plausible source but far from a certain one, especially given the presence of these two forms in most of the Austronesian CB languages. Neither the 'crocodile' nor the 'chicken' lexeme seems to be inherited in Austronesian from a node higher up the tree than Proto-SHWNG, if that. Links to any Raja Ampat languages, as will be discussed, are tentative at best, and none are present in South Halmahera. Kamholz (2014) does not find evidence for a genetic group of Cenderawasih Bay languages exclusive of Raja Ampat and South Halmahera in whose common ancestor these words could have been innovated either by borrowing or invention; more likely their widespread distribution is indicative of areal contact rather than inheritance.

(1) 'crocodile' (genus Crocodylus):

a. AN: Ambai wankori; Ansus wongkori; Pom wongkori; Serui-Laut wangkori; Biak wonkor ${ }^{12}$; Meoswar wònggòr; Waropen anggoro; Moor gwànggo; Kuri diangkara.

b. PAP: Bauzi: vama; Tunggare wama; Hatam gor; Mpur wankor; Moi wonggor; Yawa wangkori.

The \%wangkori loan set for 'crocodile' is present in most of the Austronesian CB languages. Some of the exceptions are transparent; Wamesa, for example, has innovated the forms dianggariria ${ }^{13}$ and diasinia meaning 'nasty fish' and 'fish mother', and Roon has in bebua 'big fish' in its place. Given the sound correspondences, wangkori appears to be an inherited form in SHWNG, or an early borrowing, perhaps after Tandia and Warembori with their divergent forms ivaiviza and ane-ro split off from the rest of the family. Irarutu and Kuri also have a similar form, wagri, ${ }^{14}$ for 'frog'. It is worth noting that several languages of the region have a word similar to \%gore for 'snake' (see example 28 in Appendix I), which could well be related to the 'crocodile' form.

On the non-Austronesian side, the related forms span (at least) five separate genetic groupings (assuming, as I do here, that Yawa, Hatam, and Mpur are isolates) and stretching geographically from Moi at the westernmost tip of the Bird's Head peninsula as far east as the Papua New Guinea border, where the

\footnotetext{
12 I retain van den Heuvel's (2006) spellings here; but $n k$ in Biak is pronounced [ $\mathrm{gg}$ ].

13 The Kuri word may be related to this, rather than the areal form.

14 [waygri] in Irarutu.
} 


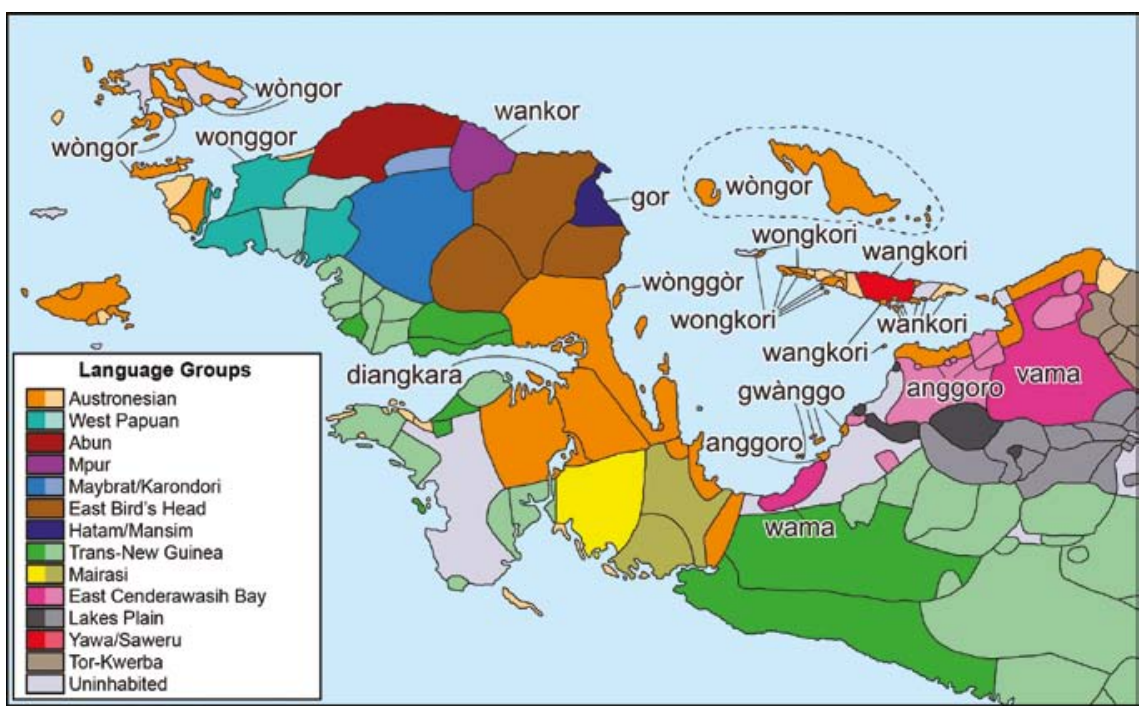

MAP 2

Distribution of \%wangkori forms for 'crocodile'. In this and following maps, callout lines are somewhat simplified for legibility.

Lakes Plain language Abawiri has a similar form (Brendon Yoder, p.c.). All of these languages (except Abawiri) are coastal, and therefore well-situated for encounters with both crocodiles and Austronesians. Though Mpur and Hatam are not located directly adjacent to any AN language, their position on the northern coast of the Bird's Head places them along the well-trafficked maritime route between the bay islands and Raja Ampat. Crocodiles were certainly not a novel species for any of the involved parties in the last 4,00o years, making the spread of this form most likely due to taboo avoidance, a practice which is still extant with regards to crocodiles in, for example, Irarutu, which has one literal and one euphemistic word for the animal (Jason Jackson p.c.), and is likely also the source of the Wamesa and Roon names cited above.

It is possible that a form found in Ambel (Remijsen, 2001), langkawai, may also be related, though this is a less clear-cut connection. The same is true of Kalamang padamuang, whose second half resembles the wang-portion of the widespread forms.

'Chicken' presents a more complex picture. Kamholz (2014; n.d.) separates the Austronesian forms into two cognate sets, what might be termed the $u$ forms in Ansus and Ambai versus the $o$-forms in Biak, Moor, Umar, Yaur, Yerisiam, and Wamesa, with Serui-Laut off on its own. I merge all of those here into a single set, with the addition of newly-collected data from other CB languages. Map 3 shows their distribution. 


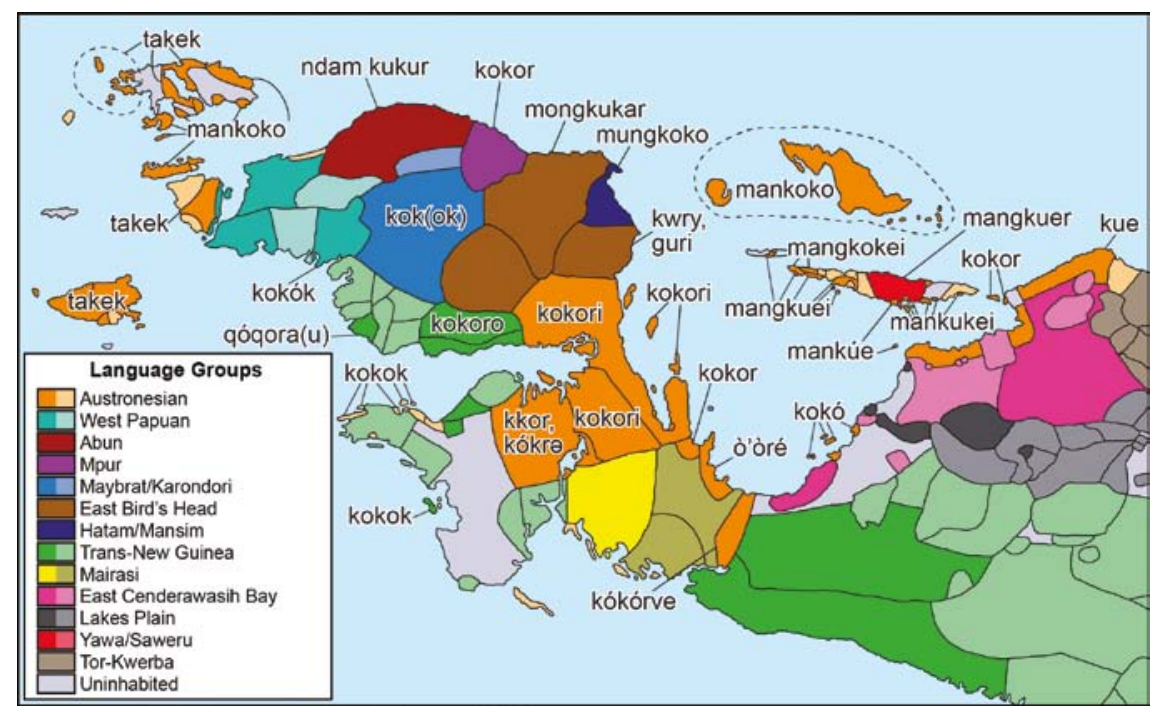

MAP 3 Distribution of \%kokor forms for 'chicken'.

(2) 'chicken' (Gallus gallus domesticus):

a. An: Ambai mankukei; Ansus mangkuei; Serui-Laut mankúe; Wamesa kokori; Pom and Wooi mangkokei; Kurudu kokor; Biak mankoko; Meoswar kokori; Roon kokori; Umar kokor; Yaur òòré; Yerisiam kókórve; Moor kokó; Warembori kue; Kuri kokori; Irarutu kkor, kókrə.

b. PAP: Maybrat kok(ok); Meyah mongkukar; Hatam kwry, guri; Mansim mungkoko; Mpur kokor; Arandai kokoro; Yawa mangkuer; Kalamang kokok; Abun ndam kukur; Tehit kokók; Inanwatan qóqora(u); Bauzi kuku.

In addition to these, Anceaux (1992) gives mengkuke for Busami and kokok for Onin, Sekar, and Arguni, three additional Central Malayo-Polynesian (CMP) languages of the Bomberai. Ambel, Matbat, and Ma'ya, our three Raja Ampat languages, have takek, the last three segments of which could be related by inheritance or borrowing, if the initial ta-can be accounted for. Within The Austronesian CB languages, the only one with an attested unrelated word is Warembori mani. The Papuan forms span every genetic lineage in the sample; the only unrelated form attested is (kalèm) tole in Moi, which may itself be a loan from Raja Ampat, where many languages have highly similar forms meaning 'egg' (Ambel talo, Matbat and Ma'ya tol, etc.); kalèm is the Moi word for 'bird'. This dataset does not include a word for 'chicken' in any of the three 
Tause varieties, but Tause Weirate has kokoapli for 'egg' where Tause Deirate has only $a b i$, suggesting that the initial koko- portion is part of the \%kokor set.

The man- portion found in some varieties is clearly of Austronesian origin, from PMP *manuk 'bird', reflexes of which appear as standalone roots in a number of SHWNG languages. Its presence in some non-Austronsian varieties strengthens the case for borrowing, despite the iconicity of the koko $(r)$ portion. A further clear connection is apparent between the forms in Yawa, Serui-Laut, Ansus, and Warembori, all of which lack the second [k]. The remaining shared forms likely flowed from a different source, with perhaps one origin, likely Biak, for the $m V n g$ - initial forms in Mansim and Meyah, and another, possibly Wamesa, for the forms without the prefix.

Reesink (1999b) says that kokor is an onomatopoetic form. This is almost certainly true :compare for example kukori and similar forms which appear in various Gujari dialects and Koshur ${ }^{15}$ (Rensch, Hallberg, and O'Leary, 1992), Sinhala kukul mas, Chichewa nkhuku, Cheyenne kokúyah, and the first two syllables of English cock-a-doodle-doo. Still, even iconicity is arbitrary to a degree, and onomatopoeia is unlikely to fully account for the range of forms here, with each non-inherited instance as an independent innovation; it is more likely that the iconicity of the word simply contributed to its widespread adoption and persistence in languages known to be in contact with one another.

A third comparably common set is \%pasa for 'rice', which appears across the region. Reesink (1999a: 611) says that this form is "found throughout the Bird's Head, including Hatam, E[ast] B[ird's] H[ead], and even S[outh] B[ird's] $\mathrm{H}[\mathrm{ead}]$ ", but declines to name the individual languages or exact word shapes involved. Similarly, other sources (Voorhoeve, 1975; Reesink, 20o2b; Voorhoeve, 1975) tend to leave it out of their wordlists, perhaps in because of its transparent status as a loan. Therefore, despite its claimed ubiquity, is it somewhat sparsely attested in my sample data. Attested distribution is shown in Map 4.

(3) 'rice' (Oryza sativa):

a. An: Wamesa pas; Ambai, Ansus, Pom, Wooi pa; Serui-Laut fa; Biak, Roon fas; Dusner pas; Waropen pako; Umar pah; Yaur pàahré; Yerisiam páhrévè; Moor pása; Warembori pasa-ro; Irarutu fas(ə); Uruangnirin fasa (Eline Visser p.c.); Ma'ya $f a^{12} s$; Matbat $f a^{3} s$; Ambel há.

b. PAP: Hatam pas; Mansim pasupra; Arandai p'ata; Moi fas; Yawa pa; Kalamang pasa; Inanwatan pásao; Tehit pasa.

15 Related languages to the east, such as Nepali and Bengali, however, use a nearly-identical form to mean 'dog'. 


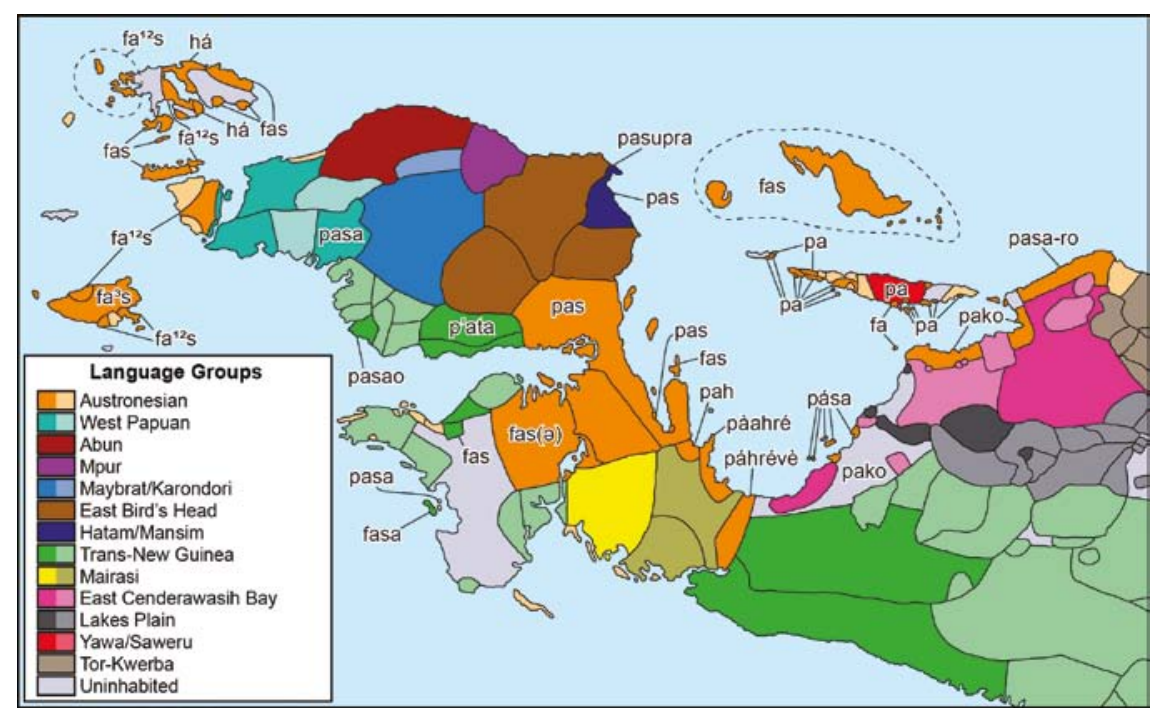

MAP 4 Distribution of \%pasa forms for 'rice'.

Rice is a relatively recent introduction into Papua from the west, so it is unsurprising that the word for it should have come in via Austronesian. Reesink (1999a: 611) puts its origin in unspecified “Western languages”, while Kamholz (2014) traces it back to PMP *pajey 'rice plant' (Blust, 1999) but attributes its appearance in some of the An languages to North Moluccan loans. Along with \%afuna 'dog', discussed below, the widespread nature of the 'chicken' and 'rice' sets fits well with observation that in Africa and Eurasia, domesticated species are commonly cited as examples of Wanderwörter.

While no other forms in this sample are quite as widespread as these three, several others do appear in multiple language groups. One notable example is the word which surfaces in Roon and Biak as waw, meaning '(sea) turtle.' ${ }^{16}$ This form is not attested in my sample in any Austronesian languages outside of Biakic, though data for this item is patchy. In Yawa, it appears as wao glossed as 'turtle'. Hatam and Mansim, however, have waw and mwaw, respectively, both with the meaning 'fish'. Apparently the word shifted from denoting one type of sea creature to another in the course of its adoption, whether the direction of borrowing was from Hatam/Mansim into Biakic or vice versa. Additionally,

16 van den Heuvel (2006) does not specify whether this can refer to sea turtles or land-based ones, though his example sentences have the turtle moving around on land. Our Roon consultant, Jim Betay, distinguished waw for 'sea turtle' (Malay penyu laut), and baiteruti for turtles on land (Malay kura-kura darat). 
unrelated Tunggare, on the southern coast of Cenderawasih Bay, has wau or uau for 'water, swim', another plausible shift in semantics.

The AN word for 'fish' appears in two Papuan languages: in in Hatam (alongside waw), and jian, pronounced [dzian], in Yawa. Based on this additional data, the most likely scenario is that waw originated in Hatam/Mansim as 'fish', moved from there into Biakic with a shift in meaning to 'sea turtle', and was then borrowed back across AN/Papuan lines into Yawa and Tunggare. Meanwhile, Hatam borrowed in 'fish' from one of the Biakic languages ; it appears almost identically in Biak, Meoswar, Roon, and Dusner. Yawa imported jian from one of the neighboring Yapen languages, which have diaN or similar. ${ }^{17}$ A similar form, *tie, is reconstructed for Proto-Lakes Plain, and may be an Austronesian borrowing. A separate 'fish' loan set appears in the Bomberai languages Kalamang (Papuan) as sor and Sekar and Arguni (Austronesian) as sair.

The word for 'louse' gives another clear case of AN to Papuan movement. 'Louse' is known to be one of the lexemes most resistant to lexical replacement over time in that family (Dyen, James, and Cole, 1967). Reconstructed to PMP as *kutu, the initial *k drops across the AN languages and some change the medial *t to [k], yielding modern $u t u$ (Yapen, Umar), $u k$ (Biakic), and similar forms. The appearance of these forms in Papuan languages is best explained by multiple independent transfer events. In Ekari, southwest of Cenderawasih Bay, the word appears $u k a$; neighboring (AN) Yerisiam has úukú. Tunggare is spoken just north of Ekari and borders on Yerisiam in the west and Moor and Serui Laut in the east; it has ?ua to Moor's küa. On the far western tip of the Bird's Head, wut in Seget almost certainly derives from one of the Raja Ampat languages, where $u t$ (Ambel, Ma'ya) and wut (Matbat) are widespread. Tandia kutuni:na, Manikion kuta and Inanwatan qóto more likely come from Indonesian or Papuan Malay, where the form is kutu with the initial $k$ retained.

'Hornbill' breaks down into two phonologically similar loan sets in the data, which may reflect two borrowing events. The Yapen Island An languages (Ambai, Ansus, Serui-Laut) have wama, as does Moi kalèm ${ }^{18}$ wama. Mainland Wamesa adds a final [r] for wamar, which is directly reflected in neighboring Arandai as wam'ore and in Tehit as qlen ${ }^{19}$ wamár. Yawa uman may also be part of this complex, but it's a further phonological stretch; Kalamang mamor, with $[\mathrm{m}]$ for initial $[\mathrm{w}]$, is a more sturdy link, though lack of attestations in other nearby languages makes its source unclear. This form has also traveled to the eastern end of Cenderawasih Bay as waman-do in Warembori; given

17 This is cognate with the Biakic form, both reflexes of PMP *hikan.
18 'bird'.
19 'bird'. 
Warembori's phonotactics a syllable-final $[\mathrm{n}]$ is expected in place of the $[\mathrm{r}]$. On the other hand are forms with medial [nd] where Yapen has [m]: Biak wando, Ambel mandawán (with the man- 'bird' prefix), Hatam undow, Mansim undow, and Mpur wandor.

\subsection{Dogs (Canis lupus subspecies)}

Perhaps the most complex Wanderwort here is 'dog'. In the West Papuan languages Moi and Seget, the forms are ofun and awfu, respectively. These most closely resemble forms found in the Austronesian languages of the Bomberai peninsula, including Arguni afun (Greenhill, Blust, and Gray 2008, from Grace), Kowiai afúna (Greenhill, Blust, and Gray 2008 from Roland Walker), Irarutu fun, and Kuri avun, and, farther afield in North Halmahera, Buli fun (Maan, 1940). Also on the Bomberai Peninsula, Papuan Mor has afuna Voorhoeve (1975). However, neither Bomberai nor Halmahera are particularly close to Moi and Seget, whose nearest AN neighbors are in Raja Ampat, where forms along the lines of yes (Biga and some Ma'ya dialects), from PMP *asu (Kamholz 2014) and kabli (other Ma'ya dialects, Gebe, Fiawat) are the norm. This distribution is likely the result of political and trade connections between Bomberai, Raja Ampat, and Ternate, which could have carried the form between the three areas. The Bomberai and N. Halmahera forms have cognates in Cenderawasih Bay (Yapen wona, Waropen una, Moor áuna) but these are different enough in pronunciation an far enough geographically that it's unlikely for them to be directly connected to the W. Papuan words. This points to an innovation in early SHWNG inherited down to the modern languages, with borrowing of the form into these Papuan languages in the last few hundred years. Whether the Irarutu form is due to an inheritance or later loan via the same channels as Mor depends on its exact place in the family tree, whether as a sister to SHWNG potentially present for the innovation, as suggested by Jason Jackson (p.c.), or integrated into Central Malayo-Polynesian (CMP), in which case the borrowing scenario must hold, as its split would have predated the SHWNG innovation. No extensive historical work has been published, but a quick comparison of sound correspondences in this sample suggests the latter. In either case, innovation of the form in (pre-)Proto-SHWNG must have coexisted for a time with the inherited PMP form, which survives in some Raja Ampat languages, and appears to have been borrowed into Mairasi as asi, perhaps via an Austronesian Bomberai language - c.f. Sekar yasi, Uruangnirin lassi (Anceaux, 1992) - or trade connections with Raja Ampat.

The picture is complicated by further data from outside the Bird's Head. There are a number of examples from Trans-New Guinea languages in eastern Papua New Guinea, far from Cenderawasih Bay and the Bird's Head, which also 
have near-identical forms: ofun in Bepour, i:bun in Miani, kawun in Maia, auna in Maria and Doromu-Koki, *sofun reconstructed in Proto-Kumil, and *kawund in Proto-North Adelbert, among others (see Greenhill n.d. and the references therein). These are geographically far removed from Mor and unrelated to Moi and Seget. Mor is itself a primary branch of TNG (Lewis, Simons, and Fennig, 2016; Greenhill n.d.), none of the other Bird's Head TNG languages represented in my sample have similar forms, and neither Pawley (2005) nor Malcolm Ross (Greenhill n.d.) reconstructs a Proto-Trans New Guinea word for 'dog'.

Mark Donohue (1995) catalogues what he considers cognate forms in Austronesian languages as far afield as kapuna in the Western Malayo-Polynesian languages Bantik, Ratahan, and South Sangir in northern Sulawesi; CMP Geser kafuna, Bati kafunai, and Watubela ahuna on Seram in Maluku; Notsi kapuna in New Ireland to the east; Kaiwa ovun in South Huon, akana in Pati in New Caledonia. These stand alongside a long list of others from eastern Indonesia to western Oceania which are less phonologically similar but still, according to Donohue, plausibly derive from the same lexical source. He cites Ross' (1992) reconstruction of Proto-Oceanic *kapun(a) 'dog', which Ross suggested originated from a non-Austronesian language of the North Adelbert Ranges family. Donohue likewise supplies a similarly lengthy list of nonAustronesian languages, both in and out of the TNG family, with a geographic span from North Halmahera to the Huon Peninsula. Donohue points out that most languages with related words are located near the coast, and comes to the conclusion that the form originated in Ternate and Tidore, spread from there through repeated borrowing via the sultanates' existing political and trade networks, and extended even beyond those boundaries south and east to island Melanesia via local contact. Neither Ternate nor Tidore currently has this form; if it was indeed present in the past, it has since been replaced by kaso, probably a loan from AN cognate with the Raja Ampat yes forms from PMP *asu. The apparent inherited nature of the CB forms suggests that the beginning of kapuna's spread predates the founding of the sultanates, and that it was perhaps borrowed from an earlier variety into Proto-SHWNG, or at least Proto-WNG. Though Moi and Seget are related to Ternate and Tidore in the West Papuan phylum, the time depth of that relationship makes it less likely that their nearly-identical forms are due to descent rather than contact.

\subsection{More Restricted Loans}

A number of additional loans appear shared between a smaller number of lineages, the majority of which originate in Austronesian. No single one of these is particularly significant on its own, but taken together they reinforce a picture 
of long-term, complex patterns of contact between the various languages of the area (see Appendix I).

Of the 70 meaning categories in this sample, 38 appear to be associated with at least one local borrowing event which crosses the AN-Papuan divide. This is in addition to the eight more widespread words listed in Section 4.1 and Section 4.2, those found only in Yawa and Austronesian, and those forms apparently borrowed among only Austronesian or only Papuan varieties. Furthermore, because of the level of similarity involved and the fact that this study compares only modern languages and not proto-forms (where these even exist), most of these loans are likely to be relatively recent, as too extreme of a time depth would allow accumulating sound changes to erode the similarity between borrowing and source beyond easy recognition. This magnitude of apparent borrowing reflects the known situation of ongoing, long-term contact between densely-packed languages. Some aspects of this distribution should not be surprising. Lexemes denoting trade and non-indigenous items (betel, rice) are known to be more prone to borrowing. Conversely, we might expect more loans into Austronesian languages of flora/fauna not present in the areas where speakers of Proto-SHWNG were settled before arriving in Papua 'cassowary' for example being a prime candidate - but none are identifiable here, perhaps due to the time depth problem. The majority of loans occurred between geographically proximate languages or along known trade routes, though source vs. recipient often cannot be identified.

Loan rates appear to be slightly higher among the languages of Cenderawasih Bay as compared to the western Bird's Head, Raja Ampat, or Bomberai, and more borrowing in coastal languages than landlocked ones like Maybrat, Moskona, and Tause. In a situation where water functions as a highway rather than an impediment to travel, this is to be expected. The preponderance of Austronesian-to-Papuan loans in cases where the source can be identified may indicate higher prestige of AN varieties, or reflect the primacy of Biak in trade along the north coast. Haynie et al. (2014) find that even words for culturally significant items, normally resistant to lexical replacement, become highly susceptible when novel uses for them are introduced, suggesting that Austronesian settlers may have introduced cultural practices and accompanying terminology for items already present in Papuan societies. Alternatively, this disparity may simply reflect our greater knowledge of Austronesian protoforms, making their descendants easier to identify than originally Papuan etyma. The temptation exists to attribute the ubiquity of forms such as \%wangkori 'crocodile' and \%kokor 'chicken' to some pre-Austronesian substrate language, and there certainly were Papuan varieties spoken in the areas subsequently colonized by Austronesians, some likely now extinct. However, the 
evidence does not present itself here to make any substantial claims about the form or content of such a substrate, or how its contributions to modern lexicons can be differentiated from simple innovations or borrowings between attested languages.

One surprise is the apparent contact between Maybrat, a landlocked language in the center of the Bird's Head, and the Biakic, Yapen, and coastal CB varieties, as well as possibly Irarutu. This appears to have been the case for 'banana', 'pig', and 'rat/mouse', examples (5), (22a), and (23) in Appendix I. In none of these cases is there an intervening coastal language with the relevant form attested, which could have served as a conduit between Maybrat and CB. Unless those intervening languages at one point also had the shared forms and in all three cases have since lost them, this supports a hypothesis of direct contact between the Maybrat and seagoing traders, either because the Maybrat would trek to the coast for trade or because of inland incursions by the seafarers.

Another surprisingly connected language is Irarutu, which appears to share forms with the Biakic languages ('pig'), Moi ('red'), Yawa ('cockatoo/parrot'), Mpur ('spider'), Hatam ('spider'), and possibly Umar ('spider'), without any attested plausible vector languages. Moi, despite its distance, is the least problematic of these, given the known Raja Ampat/Bomberai networks. The other languages, however, are located on the north coast of New Guinea and in Cenderawasih Bay. This may point to a wider previous distribution of Irarutu than is currently attested, or to more direct trade links through Kuri and Wamesa territory to the Bay.

Yawa, one of two Papuan languages on otherwise Austronesian-dominated Yapen Island, deserves an honorable mention for the sheer number of loans it has managed to absorb from the neighboring languages (see also Gasser, $2017 \mathrm{~b}$ ). Of the $7 \mathrm{o}$ lexical meanings considered, Yawa has plausibly borrowed (or loaned) at least 39 of them, one, 'white', twice. Cases not discussed previously are given in examples (39) - (61) in Appendix I, with the Yawa form compared to a few representative AN words.

Those forms which are attested in Yapen languages only, especially when their distribution even within Yapen is limited, are the strongest candidates for having originated in Yawa and spread from there into Austronesian, either as loans into Proto-Yapen or in a series of borrowing events into the individual languages or intermediate ancestors with distribution through what was almost certainly a dialect chain. The influence of Biak is also evident here.

Some loans are identifiable across Papuan familial boundaries without Austronesian involvement. Fewer of these exist than one might expect given the number of PAP/AN connections above, but bear in mind that many of those 
previously listed also cross Papuan familial boundaries. Again, these are likely to be more recent loans, and since the duration of contact between Papuan languages is roughly an order of magnitude greater than that between Papuan and Austronesian, a great many more loans are likely to exist here which have been rendered unrecognizable by sound change and semantic drift.

\subsection{Word Distributions within Austronesian}

Finally, a few forms have distributions within Austronesian that suggest that borrowing was involved. In these three cases a non-Austronesian source has not been identified, which may indicate intra-family borrowing rather than an external origin.

There are two main cognate sets within CB meaning 'green' and/or 'blue'. The first descends from PMP *mataq or *ma-qetaq 'raw, green, unripe' and is realized in CB as Moor (ma'a)ma'̂́, Yaur né/màaeè, and Yerisiam (mák)máaká (Kamholz, 2014). The other has no reconstructed antecedent, and appears as Wamesa kake, Ambai keke, Pom vekakeha, Wooi vekake, Kurudu kikes, Waropen kakesio, and possibly also Umar mkat (Kamholz, 2014), Serui-Laut kiay, and Pom vemakai, and Ansus mekae - i.e. in all of the attested Yapen languages plus Umar and Waropen (and, as noted previously, Yawa). Irarutu has similar mkrkur with the meaning 'fresh, young', which may be related. This distribution entails that either kake entered Proto-SHWNG, coexisted alongside *mataq, and was subsequently dropped in all branches except Umar, Warembori, and Yapen, or, more likely, that it entered Proto-Yapen (or its common ancestor with Umar), perhaps via contact with (Proto-)Yawa, and from there was borrowed into Waropen. It is probably a coincidence that Arandai and Kemberano have gomukake, and Tause and Tause Weirate have kaka, for 'black', though those two forms may come from a single source. (Two of those four languages, Tause and Kemberano, have unrelated words attested for 'green')

The word for 'cassowary' in most of CB as manswar or similar, but a second form appears in Wamesa as wonggei, Biak as wònge ${ }^{20}$ and Tandia as wógév'ia. Tandia was spoken in an area carved out of Wamesa territory at the base of the Wondama Peninsula, and likely got the term from Wamesa, which may also have passed it to Biak, or vice versa. As Tandia is a primary branch of SHWNG and the term does not appear elsewhere, shared inheritance can be ruled out.

A final observation regards the word for 'butterfly'. The SHWNG etymon was inherited as a root resembling apopa in most CB varieties: Wamesa

20 van den Heuvel (2006) gives manswar, wònge is from van Hasselt and van Hasselt (1947). 
(Windesi dialect) apopi; ${ }^{21}$ Ambai, Ansus, and Pom apopa; Biak àpòp; and Yerisiam kápóòpà, as well as Irarutu apapr(o). Several varieties added the manprefix to this, meaning 'bird': Tandia manipòpivia; Meoswar mampi'op, and Roon manipopi. All of the varieties to add the prefix also have the word man (manavia in Tandia) for 'bird', though the converse is not true. There is one exception to this: the Wondama dialect of Wamesa, which like most other Yapen languages has aya for 'bird', has manipopi, with the prefix, for 'butterfly' (Henning et al. 1991). Why Wondama Wamesa is the only Yapen variety to add man- (or the only one to retain it) is puzzling. Two of the other three man-ful languages, Tandia and Roon, are(/were) spoken directly adjacent to Wondama, but they are comparably small enough that such an influence seems unlikely; the third such language, Meoswar, is spoken farther up the coast adjacent to the Windesi dialect, where the man- has been dropped.

\subsection{Comparison with WOLD}

Of the 70 lexical meanings considered here, 53 have one or more counterparts in the World Loanword Database (Haspelmath and Tadmor, 2009), and it is instructive to compare findings between the two data sets, one worldwide and one tightly regional. Not all meanings are an exact one-to-one match; for example, WOLD has both 'head louse' and 'body louse' for my 'louse', and their 'parrot' maps to my 'cockatoo'. 17 forms in my sample, such as 'betel/areca nut', 'sago, 'beetle', and 'brown' are missing from theirs. (There are also 1403 WOLD entries not on my list.) Nevertheless, the overlap is significant.

Overall, my results largely align with theirs in terms of relative rates of borrowing, if not absolute numbers. Loan counts in my data should be taken as approximate; where no solid etymology or source language could be identified, all members of the resemblance set were counted as borrowings, almost certainly leading to overestimation of loan rates. If, for example, \%kokor 'chicken' were shown to be inherited throughout SHWNG and borrowed from there into the remaining varieties, its loan count would drop from 35 out of 39 forms $(90 \%)$ to 13 of 39 (33\%). Given the current state of historical reconstruction in the area, those etymologies which were identified were almost exclusively Austronesian, another source of bias.

Overall, certain or probable loans make up $25 \%$ of the total number of words in WOLD, disregarding function words (Tadmor, Haspelmath and Taylor, 2010); they make up $21 \%$ of the forms recorded in my sample. While not a large difference, it is a statistically significant one (chi-squared test, $\mathrm{p}<0.0001$ ). 
Ten of the items on the proposed Leipzig-Jakarta List of basic vocabulary are in my sample, including all of their animal names (Tadmor, Haspelmath and Taylor, 2010); for these, $8 \%$ of recorded forms are borrowed in WOLD and $14 \%$ are borrowed here. Both of these proportions are significantly $(\mathrm{p}<0.001)$ lower than in the full data set, but less dramatically so for New Guinea.

Haspelmath and Tadmor divide their items up into mutually-exclusive semantic fields, and tabulate borrowing rates for each field. The vast majority of words included in both WOLD and my sample are from the SENSE PERCEPTION, ANIMALS, FOOD AND DRINK, and AGRICULTURE AND VEGETATION fields. In their database, the Agriculture and Vegetation and Food and Drink fields are among the most commonly borrowed, with loans making up 30\% and $29 \%$ of the totals, respectively. $25 \%$ of their Animal terms are borrowed, and only $11 \%$ of Sense and Perception terms.

Using the same category for each item, FOOD AND DRINK is the most borrowed semantic category in the New Guinea sample, with loans comprising $28 \%$ of the total, followed by ANIMALS (23\%), AGRICULTURE AND VEGETATION (here plant terms; $17 \%$ ), and SENSE PERCEPTION (here color terms only; $14 \%)$. On their own, these results are somewhat suspect: Using the WOLD categorizations, only four items ('bean', 'chili pepper', 'egg', and 'fruit') fell into my FOOD category, and the first two of those are relatively recent introductions and thus highly likely to be expressed with borrowed terminology, here above $50 \%$ in both cases. Recategorizing the items into overlapping semantic fields ${ }^{22}$ and including forms not in WOLD, however, only raises FOOD's loan percentage to $29 \%$. Both indigenous ('cassava', 'coconut', 'breadfruit') and more recently introduced ('rice', 'mango', 'bean') foodstuffs have unusually high rates of borrowing, $25 \%$ or higher in these six examples. This supports the idea that historically much of the language contact in Papua resulted from trading relationships, where foods such as these were among the traded items.

Within WOLD, each lexical item is given a "borrowed score" between zero and one, where higher scores represent more borrowable words. (This does not directly correspond to the percentages given above, as it also incorporates the probability of each attested form being borrowed rather than a binary borrowed vs. inherited coding, as was applied to my data.) There is a significant correlation between a word's WOLD borrowed score and the percentage of its attestations which are borrowed in the New Guinea sample ( $<<0.01$, Pearson's

22 This recategorization limits FOOD to only (semi-)domesticated items, excluding wild species. Most entries under both ANIMALS and VEGETATION can be and are used as food in various cultural settings. 
TABLE 1 The 15 most and least borrowed wordsin this sample. Forms not included in WOLD are indicated by an asterisk.

Most borrowed words

\begin{tabular}{|c|c|c|c|c|c|}
\hline \multicolumn{3}{|c|}{ Most borrowed words } & \multicolumn{3}{|c|}{ Least borrowed words } \\
\hline Rank & Meaning & \% Borrowed & Rank & Meaning & \% Borrowed \\
\hline 1. & rice & $100 \%$ & 55 & mosquito & $5.40 \%$ \\
\hline 2. & chicken & $90 \%$ & 56. & forest & $5.10 \%$ \\
\hline 3. & cat & $84 \%$ & 57. & yellow & $4.80 \%$ \\
\hline 4. & hornbill* & $66 \%$ & 58. & banana & $4.10 \%$ \\
\hline 5. & bean & $60 \%$ & 59 . & black & $3.90 \%$ \\
\hline 6. & chili pepper & $52 \%$ & $6 o$. & (tree) kangaroo/ & $3.40 \%$ \\
\hline 7. & breadfruit* & $48 \%$ & & wallaby & \\
\hline 8. & cockroach & $47 \%$ & 61. & yam/ & $3.10 \%$ \\
\hline 9. & blue & $46 \%$ & & sweet potato & \\
\hline 10. & papeda* & $45 \%$ & 62. & beetle* & $0 \%$ \\
\hline 11. & cassava & $44 \%$ & 62. & branch & o\% \\
\hline 12. & wasp/bee & $42 \%$ & 62. & brown* & $0 \%$ \\
\hline 13. & crocodile & $41 \%$ & 62. & casuarina tree* & $0 \%$ \\
\hline 14. & sago* & $39 \%$ & 62. & grasshopper & o\% \\
\hline \multirow[t]{3}{*}{15} & owl & $36 \%$ & 62. & pumpkin/gourd & $0 \%$ \\
\hline & & & 62. & sky & $0 \%$ \\
\hline & & & 62. & sprout* & o\% \\
\hline
\end{tabular}

\section{Least borrowed words}

$r=0.387$ ), but the match is far from perfect. Table 1 gives the fifteen most and least often borrowed items in my sample, calculated as the percentage of attested forms deemed likely to be loans. Starred items in my sample were not present in WOLD, which only contains 53 of the 70 meanings on my list. Table 2 ranks the items on my wordlist by their WOLD Borrowed Score. Where two WOLD items corresponded to one on my list, as with 'yam' and 'sweet potato', their borrowed scores were averaged here.

There is significant overlap between the two samples in their least and most borrowed forms. 'Rice', 'chicken', 'chili' pepper', and 'bean' show up in both sets' top ten, and 'cat', 'cockroach', 'crocodile', and 'cassava' are in the top 15 . On the low end, 'yellow', 'black', and 'grasshopper' are in the least-loaned 15 from both sets. Notable mismatches include 'owl' (NG \#15; WOLD \#39), 'wasp/bee' (NG \#12; WOLD \#39), 'banana' (NG \#58; WOLD \#2), '(tree) kangaroo/wallaby' 
TABLE 2 The 15 most and least borrowed words from my list as ranked by each item's Borrowed Score in WOLD. Where two WOLD entries corresponded to one item in my list, their Borrowed Scores were averaged.

\begin{tabular}{|c|c|c|c|c|c|}
\hline \multicolumn{3}{|c|}{ Most borrowed } & \multicolumn{3}{|c|}{ Least borrowed } \\
\hline Rank & Meaning & Borrowed Score & Rank & Meaning & Borrowed Score \\
\hline 1. & kangaroo & 0.84 & 39. & owl & 0.15 \\
\hline 2. & banana & 0.62 & 39. & wasp/bee & 0.15 \\
\hline 2. & rice & 0.62 & 39. & yellow & 0.15 \\
\hline 4. & crocodile & 0.53 & 42. & butterfly & 0.14 \\
\hline 5. & parrot & 0.5 & 43. & worm & 0.12 \\
\hline 6. & coconut & 0.49 & 44. & ant & 0.12 \\
\hline 7. & cassava & 0.43 & 44. & grasshopper & 0.11 \\
\hline 8. & bean & 0.41 & 45 . & dark & 0.1 \\
\hline 8. & chili pepper & 0.41 & 45 . & leaf & 0.1 \\
\hline 10. & chicken & 0.37 & 47. & egg & 0.09 \\
\hline 11. & cockroach & 0.36 & 48. & red & 0.07 \\
\hline 12. & cat & 0.34 & $5^{0 .}$ & root & 0.06 \\
\hline 13. & pumpkin/gourd & 0.33 & $5^{1 .}$ & black & 0.05 \\
\hline \multirow[t]{2}{*}{13.} & yam/ & 0.33 & $5^{1 .}$ & fly & 0.05 \\
\hline & sweet potato & & $5^{1 .}$ & louse & 0.05 \\
\hline 15 & pig & 0.3 & & & \\
\hline
\end{tabular}

(NG \#6o, WOLD \#1), 'yam/sweet potato' (NG \#61; WOLD \#13), and 'pumpkin/ gourd' (NG \#62; WOLD \#13). This suggests that, while the WOLD patterns may well hold on a global scale, the details of each individual contact situation can lead to notable variation at the regional level.

\subsection{Borrowings by Language and the Nature of Contact}

What can all this tell us about the socio-linguistic situation in Papua over the last 3500 years or longer? The volume of loan words, particularly those which might be considered "basic" vocabulary, suggests fairly intense, long-term interaction between language groups, likely including a fair level of bilingualism. Little has been reported about current levels of bi/multi-lingualism overall, but in my experience it appears to be fairly common. Papuan Malay and related lects serve as a lingua franca, particularly in the cities and coastal areas, and 
have for the last 130 or so years (Kluge, 2014). Wamesa has served as a local lingua franca in southwest Cenderawasih Bay, and Biak for a larger area.

Given the difficulties determining direction of borrowing for many of the loans discussed here, it is hard to determine what lingua francas may have existed further back in history, as specific donor languages are often impossible to identify. Instead, we might look for tell-tale distributions within loan sets. If they are acting as vehicles for loans throughout the area, we might expect a lingua franca to a) be part of many loan sets, as it interacts with a range of other languages, and $b$ ) be part of large loan sets, appearing as the center of a starburst dispersing the same word to a number of other varieties. For the first measure, the top ten languages ${ }^{23}$ are all from coastal and island Cenderawasih Bay, with the exceptions of Moi (\#6) and Irarutu (\#8). There is a strong correlation, however, between the number of sets a language is part of and how well documented it is : a language with more words attested in the list will be part of more loan sets. For the second measure, the top slots are strongly skewed towards those languages only represented in the largest loan sets, so the least well documented and those with very few loans are over-represented.

To balance these conflicting skews, I instead use a measure I'll call 'connectedness'. A language's connectedness score is the product of the number of loan sets it takes part in and the average size of those sets. By this measure, the 10 most connected languages - Ambai, Wamesa, Yawa, Ansus, Serui-Laut, Roon, Wooi, Biak, Pom, Yerisiam - are all Austronesian languages spoken in coastal and Island Cenderawasih Bay, with the exception of Yawa, at \#3. All but four are spoken on Yapen Island, and one of those, Wamesa, has its closest relatives there. This may suggest that proto-Yapen was a lingua franca responsible for spreading loans around the bay, or simply that Yapen languages share a lot of vocabulary with each other, much of which has been borrowed outside of that group from one source or another. The eleventh-most-connected language, Irarutu, shows more promise as a lingua franca. It occupies an area connecting the Bomberai languages, the southern Bird's Head, and the Bird's neck, and is not closely related to any of the SHWNG languages, mitigating the effects of inheritance. In general, however, these patterns seem to point more towards many smaller, local exchanges rather than a small number of broad regional lingua francas binding large groups of languages together. Still quite a bit more historical work to determine donor vs. recipient languages is necessary to confirm this.

23 For these calculations, known inheritances were included in each loan set, so as not to exclude the donor languages they are attempting to find; this means that for widely inherited forms the size of the loan set will be artificially inflated. 
Looking at simply percentage of vocabulary comprised of loans, Yawa is by far the most prolific borrower, with $5^{2} \%$ of its attested forms here borrowed from elsewhere. Sitting in the middle of Yapen Island, surrounded by those well-connected Yapen languages, Yawa seems to have adopted their vocabulary wholesale, probably through constant trade and a prestige differential favoring the Austronesians, and quite possibly through widespread multilingualism. The high percentages of loans in Ambai (44\%), Wooi (40\%), and Serui-Laut $(38 \%)$ suggests that that relationship may not have been entirely one-sided. Gasser $(2017 \mathrm{~b})$ suggests that the nature and extent of borrowing, both lexical and grammatical, suggests a history of widespread multilingualism and intermarraige, which should not be surprising given current practices. Mansim $(39 \%)$, Wamesa (35\%), and Seget (33\%) also have high levels of borrowing. On the other end, only three to four percent of these words in Awera, Rasawa, Manikion, and inland Tause are involved in borrowing events, despite the fact that Awera and Rasawa are on the coast quite near the prolifically connected Yapen languages. Duriankere, in Raja Ampat, and Moskona, inland in the Bird's Head, have no identified loans in this sample. ${ }^{24}$ The nine languages with the lowest rates of loan involvement are all Papuan; the tenth-lowest, Tandia, belongs to SHWNG. There is a weak but statistically significant $(\mathrm{p}=0.025)$ correlation between the number of attested forms for a language on this list and the proportion of those forms which are involved in borrowing: collecting synonyms means unearthing more borrowed forms.

\section{5}

\section{Conclusions}

It is clear from the data presented here that contact between the Papuan and Austronesian languages of the Bird's Head and Cenderawasih Bay has been ongoing and extensive. Explicitly quantifying levels of borrowing would be difficult, given the large number of cases where determining the source vs. recipient varieties is so far impossible. Still, it is clear that overall the amount of borrowing is high, though quite variable, with Mor on the lower end with regards to this sample, perhaps for geographical reasons, and Yawa on the extreme upper end. While borrowings flow in both directions, the overwhelming current appears to proceed from Austronesian into Papuan lexicons. While several possible explanations for this directionality present themselves, and the time depth at which it operates may be limited, this suggests that (preIndonesian) Austronesian speakers were influential in the region, serving as

24 Note, however, that Duriankere has only seven attested forms here. 
conduits for coastal trade and introducing new uses for potentially pre-existing items. Their arrival, with their trademark outrigger canoes, may even have contributed to an increase in connectivity, and therefore borrowing, in the region, as is known to have happened in Central Asia with the introduction of transport-related technology such as horse domestication and the chariot (Jonathan Washington p.c.). Future work, both on detailed documentation and historical reconstruction, will further clarify directionality of borrowing and more details of the contact situation.

\section{Acknowledgement}

Many thanks to various colleagues cited herein for sharing their data; my research assistant Claire Benham-Chandler for aggregating and organizing most of the lexical forms cited here; the Yusuf Sawaki and the CELD for support in the field; Antoinette Schapper and participants at the December 2016 Workshop on Papuan-Austronesian Contact in Wallacea; Matt Zucker for mapping expertise; and all of the speakers who shared their languages with me, especially Ibu Marice Karubuy (Wamesa). This work was supported by the National Science Foundation DEL under Grant 1153795, as well as by Swarthmore College and the Max Planck Institute for the Science of Human History.

\section{References}

Anceaux, J.C. 1992. Irian Jaya source materials: The J.C. Anceaux collection of wordlists of Irian Jaya, vol. 1 and (B 1). Leiden/Jakarta: Department of Languages and Cultures of South-East Asian and Oceania, Leiden University.

Arnold, Laura. 2018. A Grammar of Ambel: An Austronesian language of Raja Ampat, west New Guinea. PhD dissertation, University of Edinburgh.

Bellwood, Peter. 1995. Austronesian prehistory in Southeast Asia: Homeland, expansion and transformation. In Peter Bellwood, James J. Fox and Darrell Tryon (eds.), The Austronesians: Historical and Comparative Perspectives, 103-118. Canberra: ANU E Press.

Bellwood, Peter. 1998. From Bird's Head to bird's eye view: Long term structures and trends in Indo-Pacific prehistory. In Jelle Miedema, Cecilia Odé and Rien A.C. Dam (eds.), Perspectives on the Bird's Head of Irian Jaya, Indonesia: Proceedings of the Conference. Amsterdam: Rodopi.

Bellwood, Peter. 2007. Prehistory of the Indo-Malaysian Archipelago. Honolulu: University of Hawaii Press. 
Berry, Keith and Christine Berry. 1999. A Description of Abun: A West Papuan Language of Irian Jaya. Canberra: Pacific Linguistics.

Berry, Keith and Christine Berry. 2000. Abun. In Ger P. Reesink (ed.), Studies in Irian Languages, Part II, vol. 47, NUSA - Linguistic Studies of Indonesian and Other Languages in Indonesia, 35-44. Tokyo: Research Institute for Languages and Cultures of Asia and Africa.

Blust, Robert. 1978. Eastern Malayo-Polynesian: A subgrouping argument. In S.A. Wurm and Lois Carrington (eds.), Second International Conference on Austronesian Linguistics: Proceedings, 181-254. Canberra: Department of Linguistics, Research School of Pacific Studies, Australian National University.

Blust, Robert. 1993. Central and Central-Eastern Malayo-Polynesian. Oceanic Linguistics 32. 241-293.

Blust, Robert. 1999. Subgrouping, circularity and extinction: some issues in Austronesian comparative linguistics. In Selected Papers from the 8th International Conference on Austronesian Linguistics, vol. 1, 31-94.

Blust, Robert. 2002. The history of faunal terms in Austronesian languages. Oceanic Linguistics 41(1). 89. DOI: 10.2307/3623329.

Blust, Robert. 2012. The marsupials strike back: A reply to Schapper (2011). Oceanic Linguistics 51(1). 261-277.

Blust, Robert and Stephen Trussel. 2010. Austronesian comparative dictionary. Online database. http://www.trussel2.com/acd/.

Bowern, Claire, Patience Epps, Russell Gray, Jane Hill, Keith Hunley, Patrick McConvell and Jason Zentz. 2011. Does lateral transmission obscure inheritance in huntergatherer language? PLoS ONE 6(9).

Bowern, Claire, Hannah Haynie, Catherine Sheard, Barry Alpher, Patience Epps, Jane Hill and Patrick McConvell. 2014. Loan and inheritance patterns in hunter-gatherer ethnobiological systems. Journal of Ethnobiology 34(2). 195-227.

Briley, David. 1976. Bauzi phonology. Irian: Bulletin of Irian Jaya Development 5(1). 47-65.

Briley, Joyce. 1976. An overview of the Bauzi verb phrase. Irian: Bulletin of Irian Jaya Development $5(2) \cdot 3^{-17}$.

Campbell, Lyle and Mauricio J. Mixco. 2007. A Glossary of Historical Linguistics. Edinburgh: Edinburgh University Press.

Clouse, Duane A. 1997. Towards a reconstruction and reclassification of the Lakes Plain languages of Irian Jaya. In K. Franklin (ed.), Papers in Papuan linguistics no. 2. Canberra: Pacific Linguistics.

Clouse, Heljä and Duane Clouse. 1993. Kirikiri and the Western Lakes Plain languages: Selected phonological phenomena. Language and Linguistics in Melanesia 24. 1-18. Dalrymple, Mary and Suriel Mofu. 2012. Dusner (Languages of the World/Materials 4887). Munich: LINCOM GmbH. 
Dalrymple, Mary and Suriel Mofu. n.d. Multimodal language documentation for Dusner, an endangered language of Papua. http://dusner.clp.ox.ac.uk/.

Denham, Tim. 2004. The roots of agriculture and arboriculture in New Guinea: Looking beyond Austronesian expansion, Neolithic packages and indigenous origins. World Archaeology 36(4). 610-620. DOI: 10.1080/0043824042000303791.

Denham, Tim. 2010. From domestication histories to regional prehistory: Using plants to re-evaluate early and mid-Holocene interaction between New Guinea and Southeast Asia. Food and History 8(1). 3-22.

Dobney, Keith., Thomas. Cucchi and Greger Larson. 2008. The pigs of Island Southeast Asia and the Pacific: New evidence for taxonomic status and human-mediated dispersal. Asian Perspectives 47(1). 59-74. DoI: 10.1353/asi.2008.00o9.

Dol, Philomena. 2007. A Grammar of Maybrat: A Language of the Bird's Head Peninsula, Papua Province, Indonesia. Canberra: Pacific Linguistics.

Donohue, Mark. 1995. Barking up the wrong tree: Chasing an Oceanic dog west to Indonesia. In C. Baak, M. Bakker and D. van der Meij (eds.), Tales from a Concave World: Liber Amicorum Bert Voorhoeve, 216-45. Leiden: Department of Languages and Cultures of Southeast Asia and Oceania, Leiden University.

Donohue, Mark. 1997. Hatam phonology and grammatical notes. In Andrew Pawley (ed.), Papers in Papuan Linguistics (Series A-87 3), 37-57. Canberra: Pacific Linguistics.

Donohue, Mark. 1999. Warembori, vol. 341, Languages of the World/Materials. Munich: Lincom Europa.

Donohue, Mark, David Price, Selfius and Nico. n.d. Ansus - daftar kata bahasa Ansus Ansus wordlist.

Dyen, Isidore, A.T. James and J.W.L. Cole. 1967. Language divergence and estimated word retention rate. Language 43(1). 150-171.

Foley, William A. 2010. Language contact in the New Guinea region. In Raymond Hickey (ed.), The Handbook of Language Contact, 785-813. Boston: Wiley-Blackwell.

Franklin, Karl J. 1975. Comments on Proto-Engan. New Guinea Area Languages and Language Study 1. 263-275.

Fuller, Dorian, Nicole Boivin, Tom Hoogervorst and Robin Allaby. 2011. Across the Indian Ocean: The prehistoric movement of plants and animals. Antiquity 85(328). 544-558.

Gasser, Emily. 2014. Windesi Wamesa Morphophonology. PhD dissertation, Yale University.

Gasser, Emily. 2015. Wamesa Talking Dictionary. Living Tongues Institute for Endangered Languages. http://talkingdictionary.org/wamesa.

Gasser, Emily. 2016. Pom Talking Dictionary. Living Tongues Institute for Endangered Languages. http://talkingdictionary.org/pom. 
Gasser, Emily. 2017a. Ansus Talking Dictionary. Living Tongues Institute for Endangered Languages. http://talkingdictionary.org/ansus.

Gasser, Emily. 2017b. Papuan-Austronesian Language Contact on Yapen Island: A Preliminary Account. In Antoinette Schapper (ed.), NUSA 62, Contact and Substrate in the Languages of Wallacea Part 1, 103-158. DoI: 10.15026/89845.

Gasser, Emily. 2018. Biak Talking Dictionary. Living Tongues Institute for Endangered Languages. http://talkingdictionary.org/biak.

Gasser, Emily and David Gil. 2016. Roon Talking Dictionary. Living Tongues Institute for Endangered Languages. http://talkingdictionary.org/roon.

Glover, Ian C. 1979. Prehistoric plant remains from Southeast Asia, with special reference to rice. In M Taddei (ed.), South Asian Archaeology 1977, vol. I, 7-37. Naples: Istituto Universitario Orientale.

Golson, Jack. and P. J. Hughes. 1980. The appearance of plant and animal domestication in New Guinea. Journal de la Société des Océanistes 36(69). 294-303. DoI: 10.3406/jso.1980.3044.

Gonzalez, Juan-Carlos T., Ben C. Sheldon, Nigel J. Collar and Joseph A. Tobias. 2013. A comprehensive molecular phylogeny for the hornbills (Aves: Bucerotidae). Molecular Phylogenetics and Evolution 67(2). 468-483. DOI: 10.1016/j.ympev.2013.02.012.

Gorecki, Paul, Mark Mabin and John Campbell. 1991. Archaeology and geomorphology of the Vanimo Coast, Papua New Guinea: Preliminary results. Archaeology in Oceania 26(3). 119-122.

Grace, George. 1955-56. Field notebooks. http://digicoll.manoa.hawaii.edu/grace/ Pages/PDFlist.html.

Gravelle, Gilles. 2000. Meyah. In Ger P. Reesink (ed.), Studies in Irian Languages, Part II, vol. 47, NUSA - Linguistic Studies of Indonesian and Other Languages in Indonesia, 72-104. Tokyo: Research Institute for Languages and Cultures of Asia and Africa.

Gravelle, Gilles. 2002. Morphosyntactic properties of Meyah word classes. In Ger P. Reesink (ed.), Languages of the Eastern Bird's Head, chap. 13, 109-181. Canberra: Pacific Linguistics.

Gravelle, Gilles and Gloria Gravelle. 1999. A brief comparison of Meyah and Moskona linguistic features. Irian Jaya, Indonesia: SIL. Unpublished ms.

Greenhill, Simon. n.d. Transnewguinea.org. Lexical database. http://transnewguinea $.0 r g /$.

Greenhill, Simon J., Robert Blust and Russell D. Gray. 2008. The Austronesian Basic Vocabulary Database: From bioinformatics to lexomics. Evolutionary Bioinformatics 4. $271-283$.

Haspelmath, Martin and Uri Tadmor (eds.). 2009. WOLD. Leipzig: Max Planck Institute for Evolutionary Anthropology. URL http://wold.clld.org/. 
van Hasselt, Johannes L. and Frans Johannes Frederik van Hasselt. 1947. Noemfoorsch Woordenboek. Amsterdam: N.V. Drukkerij en Uitgeverij J.H. de Bussy.

Haynie, Hannah, Claire Bowern, Patience Epps, Jane Hill and Patrick McConvell. 2014. Wanderwörter in languages of the Americas and Australia. Ampersand 1. 1-18.

Heinsohn, Tom. 2002. Animal translocation: long-term human influences on the vertebrate zoogeography of Australasia (natural dispersal versus ethnophoresy). Australian Zoologist 32(3) $35^{1-376 . ~}$

Held, Gerrit Jan. 1942. Grammatica van het Waropensch (Nederlandsch Noord NieuwGuinea). Bandung: Nix.

Henning, Jean C., Theodore A. Henning, Mina Sawaki, Okta Netty Mananian, Tomas Yoteni and Dorce Webori-Mamori. 1991. Sane pai ve pir kavavo nana kavo Wondama/ Perbendahara'an kata bahasa Wandamen/Wandamen Vocabulary (Series B, Publikasi Khusus Bahasa-Bahasa Daerah 8). Irian Jaya, Indonesia: Universitas Cenderawasih and Summer Institute of Linguistics.

Hesse, Ronald. 2000. Tehit. In Ger P. Reesink (ed.), Studies in Irian Languages, Part II, vol. 47, NUSA - Linguistic Studies of Indonesian and Other Languages in Indonesia, 25-33. Tokyo: Research Institute for Languages and Cultures of Asia and Africa.

van den Heuvel, Wilco. 2006. Biak: Description of an Austronesian Language of Papua. PhD dissertation, Vrije Universiteit Amsterdam.

Holton, Gary. 2017. A unified system of spatial orientation in the Austronesian and non-Austronesian languages of Halmahera. In Antoinette Schapper (ed.), NUSA: Contact and Substrate in the Languages of Wallacea Part 1, Vol. 62, 157-89.

Jackson, Jason Alexander Johann. 2014. A Grammar of Irarutu, a Language of West Papua, Indonesia, with Historical Analysis. PhD dissertation, University of Hawai'i at Manoa.

Jones, Linda. 1986a. The question of ergativity in Yawa, a Papuan language. Australian Journal of Linguistics 6(1). 37-55.

Jones, Linda. 1986b. Yawa phonology. Pacific Linguistics 74. Series A, Occasional papers.

Jones, Linda K., Yohanes Paai and Zet Paai. 1989. Ayao Yawa mo mona nanentabo ranugan - Perbendaharaan kata bahasa Yawa - Yawa vocabulary, Publikasi khusus bahasa-bahasa daerah, seri B. Cenderawasih University and Summer Institute of Linguistics.

Kamholz, David. 2014. Austronesians in Papua: Diversification and Change in South Halmahera-West New Guinea. PhD dissertation, University of California at Berkeley.

Kamholz, David. n.d. Lexifier. online database. http://lexifier.lautgesetz.com.

Kennedy, Jean. 2008. Pacific bananas: Complex origins, multiple dispersals? Asian Perspectives $47(1) \cdot 75^{-94}$. 
Klamer, Marian. 2002. Typical features of Austronesian languages in Central/Eastern Indonesia. Oceanic Linguistics 41(2). 363-383.

Kluge, Angela. 2014. A Grammar of Papuan Malay. PhD dissertation, Universiteit Leiden.

Kraft, Kraig H, Cecil H Brown, Gary P Nabhan, Eike Luedeling, José de Jesús Luna Ruiz, Geo Coppens d'Eeckenbrugge, Robert J Hijmans and Paul Gepts. 2014. Multiple lines of evidence for the origin of domesticated chili pepper, Capsicum annuum, in Mexico. Proceedings of the National Academy of Sciences 111(17). 6165-6170.

Larson, Greger, Thomas Cucchi, Masakatsu Fujita, Elizabeth Matisoo-Smith, Judith Robins, Atholl Anderson, Barry Rolett, Matthew Spriggs, Gaynor Dolman, Tae-Hun Kim, Nguyen Thi Dieu Thuy, Ettore Randi, Moira Doherty, Rokus Awe Due, Robert Bollt, Tony Djubiantono, Bion Griffin, Michiko Intoh, Emile Keane, Patrick Kirch, Kuang-Ti Li, Michael Morwood, Lolita M. Pedriña, Philip J. Piper, Ryan J. Rabett, Peter Shooter, Gert Van den Bergh, Eric West, Stephen Wickler, Jing Yuan, Alan Cooper and Keith Dobney. 2007. Phylogeny and Ancient DNA of Sus Provides Insights into Neolithic Expansion in Island Southeast Asia and Oceania. Proceedings of the National Academy of Sciences of the United States of America 104(12). 4834-4839.

Lebot, Vincent. 1999. Biomolecular evidence for plant domestication in Sahul. Genetic Resources and Crop Evolution 46(6). 619-628.

van der Leeden, Alexander Cornelis. N.d. Maya: A Language Study. Dictionary, Morphology, and Syntax. Jakarta and Leiden: LIPI-RUL. Unpublished ms.

Lewis, M. Paul, Gary F. Simons and Charles D. Fennig (eds.). 2016. Ethnologue: Languages of the world. Dallas: SIL International, 19th edn. Online version: http://www .ethnologue.com/.

Lichtenberk, Frantisek. 1998. Did speakers of Proto Oceanic chew betel? The Journal of the Polynesian Society 107(4). 335-363.

Lilley, Ian. 1998. East of Irian: Archaeology in Papua New Guinea. In Gert-Jan Bartstra (ed.), Bird's Head Approaches, Irian Jaya Studies - A Programme for Interdisciplinary Research, chap. 8, 135-156. Rotterdam: A.A. Balkema.

Lynch, John. 1981. Austronesian "loanwords"(?) in Trans-New Guinea phylum vocabulary. Pacific Linguistics 61. Series A: Occasional papers.

Maan, G. 1940. Boelisch-Nederlandse woordenlijst. In Verhandelingen van het Bataviaasch Genootschap van Kunsten en Wetenschappen, vol. 47.

Matisoo-Smith, Elizabeth. 2009. The commensal model for human settlement of the Pacific 10 years on-What can we say and where to now? The Journal of Island and Coastal Archaeology 4(2). 151-163. DOI: 10.1080/15564890903155273.

Matsumura, Takashi. 1991. Irarutu phonology. In Workpapers in Indonesian Languages and Culture, 37-74. SIL.

Matthews, Peter J. 1995. Aroids and the Austronesians. Tropics 4(2/3).105-126. 
McElhanon, K.A. and C.L. Voorhoeve. 1970. The Trans-New Guinea Phylum: Explorations in Deep-Level Genetic Relationships. Canberra: Pacific Linguistics.

McGibbon, Rodd. 2004. Plural Society in Peril: Migration, Economic Change, and the Papua Conflict, vol. 13, Policy Studies. Washington, DC: East-West Center Washington.

Menick, Raymond H. 1996. Verb sequences in Moi. In Ger P. Reesink (ed.), Studies in Irian Languages, Part II, vol. 40, NUSA - Linguistic Studies of Indonesian and Other Languages in Indonesia, 41-6o. Tokyo: Research Institute for Languages and Cultures of Asia and Africa.

Menick, Raymond H. 2000. Moi. In Ger P. Reesink (ed.), Studies in Irian Languages, Part II, vol. 47, NUSA - Linguistic Studies of Indonesian and Other Languages in Indonesia, 7-24. Tokyo: Research Institute for Languages and Cultures of Asia and Africa.

Michaux, B. 1994. Land movements and animal distributions in east Wallacea (eastern Indonesia, Papua New Guinea and Melanesia). Palaeogeography, Palaeoclimatology, Palaeoecology $112(3-4) \cdot 323-343$.

Miedema, J. and F.I. Welling. 1985. Fieldnotes on languages and dialects in the Kebar district, Bird's Head, Irian Jaya. In K.R. Adams et al. (ed.), Papers in New Guinea Linguistics no. 22, 29-52. Canberra: Pacific Linguistics.

Nenepat, Eklevina Creszentia. 2012. A Comparison of Dusner and Biak Phonological System. Undergraduate thesis, Fakultas Sastra, Universitas Negeri Papua.

Odé, Cecelia. 2002. A sketch of Mpur. In Ger P. Reesink (ed.), Languages of the Eastern Bird's Head, chap. 2, 45-108. Canberra: Pacific Linguistics.

Odé, Cecilia. 2004. Mpurvocabulary - daftar kata Mpur, vol. A1-009. Osaka and Leiden: Endangered Languages of the Pacific Rim and Leiden University.

Bill Palmer (ed.). 2018. The Languages and Linguistics of the New Guinea Area: A Comprehensive Guide. Berlin/Boston: De Gruyter Mouton.

Pasveer, Juliette M., Simon J. Clarke and Gifford H. Miller. 2002. Late Pleistocene human occupation of inland rainforest, Bird's Head, Papua. Archaeology in Oceania 37(2). 92-95.

Pawley, Andrew. 2005. The chequered career of the Trans New Guinea hypothesis: Recent research and its implications. In A. Pawley, R. Attenborough, J. Golson and R. Hide (eds.), Papuan Pasts: Cultural, Linguistic and Biological Histories of PapuanSpeaking Peoples, 67-107. Canberra: Pacific Linguistics.

Piper, Philip J. 2017. The origins and arrival of the earliest domestic animals in Mainland and Island Southeast Asia: A developing story of complexity. In Philip J. Piper, Hirofumi Matsumura and David Bulbeck (eds.), New Perspectives in Southeast Asian and Pacific Prehistory (Terra Australis 45), chap. 15, 251-274. Canberra: ANU Press.

Reesink, Ger P. 1996. Morpho-syntactic features of the Bird's Head, part 1. In Ger P. Reesink (ed.), Studies in Irian Languages, vol. 40, NUSA - Linguistic Studies of 
Indonesian and Other Languages in Indonesia, 40: 1-20. Research Institute for Languages and Cultures of Asia and Africa.

Reesink, Ger P. 1999a. The Bird's Head as sprachbund. In Jelle Miedema, Cecilia Odé, Rien A.C. Dam and Connie Baak (eds.), Persectives on the Bird's Head of Irian Jaya, Indonesia. Amsterdam: Rodopi. Proceedings of the Conference, Leiden 13-17 October 1997.

Reesink, Ger P. 1999b. A Grammar of Hatam, vol. 146, C. Canberra: Pacific Linguistics. Reesink, Ger P. 2000a. Hatam. In Ger P. Reesink (ed.), Studies in Irian Languages, Part II, vol. 47, NUSA - Linguistic Studies of Indonesian and Other Languages in Indonesia, 131-137. Tokyo: Research Institute for Languages and Cultures of Asia and Africa.

Reesink, Ger P. 20oob. Sougb. In Ger P. Reesink (ed.), Studies in Irian Languages, Part II, vol. 47, NUSA - Linguistic Studies of Indonesian and Other Languages in Indonesia, 105-129. Tokyo: Research Institute for Languages and Cultures of Asia and Africa.

Reesink, Ger P. 2002a. The eastern Bird's Head languages compared. In Ger P. Reesink (ed.), Languages of the Eastern Bird's Head, chap. 1, 1-44. Canberra: Pacific Linguistics.

Reesink, Ger P. 2002b. A grammar sketch of Sougb. In Ger P. Reesink (ed.), Languages of the Eastern Bird's Head, chap. 4, 181-276. Canberra: Pacific Linguistics.

Reesink, Ger P. 2002c. Mansim, a lost language of the Bird's Head. In Ger P. (ed.), Languages of the Eastern Bird's Head, chap. 5, 277-340. Canberra: Pacific Linguistics.

Reesink, Ger and Michael Dunn. 2018. Contact phenomena in Austronesian and Papuan languages. In Bill Palmer (ed.), The Languages and Linguistics of the New Guinea Area: A Comprehensive Guide, 939-985. Berlin/Boston: De Gruyter Mouton.

Remijsen, Bert. 2001. Word-Prosodic Systems of Raja Ampat Languages. Utrecht: LOT.

Remijsen, Bert. 2015. Matbat_MageyDialect_2003_Lexicography, 1998-2003 [text]. University of Edinburgh. School of Philosophy, Psychology and Language Sciences. Linguistics and English Language. http://dx.doi.org/10.7488/ds/262.

Rensch, Calvin R., Calinda E. Hallberg and Clare F. O'Leary. 1992. Sociolinguistic Survey of Northern Pakistan Volume 3: Hindko and Gujari. Islamabad, Pakistan and High Wycombe, UK: National Institute of Pakistan Studies and SIL.

Roberts, Mere. 1991. Origin, dispersal routes, and geographic distribution of Rattus exulans, with special reference to New Zealand. Pacific Science 45(2). 123-130.

Ross, Malcolm. 1992. Reconstructing the linguistic history of the Madang province, PNG: A progress reoprt. Seminar, Research School of Pacific Studies, Canberra.

Ross, Malcolm. 2005. Pronouns as a preliminary diagnostic for grouping Papuan languages. In A. Pawley, R. Attenborough, J. Golson and R. Hide (eds.), Papuan Pasts: Cultural, Linguistic and Biological Histories of Papuan-Speaking Peoples, 15-65. Canberra: Pacific Linguistics. 
Ross, Malcolm. 2014. Unpublished reconstructions. Reported in transnewguinea.org. Rowe, Kevin C., Michael L. Reno, Daniel M. Richmond, Ronald M. Adkins and Scott J. Steppan. 2008. Pliocene colonization and adaptive radiations in Australia and New Guinea (Sahul): Multilocus systematics of the old endemic rodents (Muroidea: $\mathrm{Mu}$ rinae). Molecular Phylogenetics and Evolution 47(1). 84-101. DoI: 10.1016/j.ympev .2008.01.001.

Sawaki, Yusuf. 2017. A Grammar of Wooi: An Austronesian Language of Yapen Island, Western New Guinea. PhD dissertation, The Australian National University.

Schapper, Antoinette. 2011. Phalanger facts: Notes on Blust's marsupial reconstructions. Oceanic Linguistics 50(1). 258-272.

Schapper, Antoinette (ed.). 2017. Contact and Substrate in the Languages of Wallacea Part 1, vol. 62, NUSA - Linguistic Studies of Indonesian and Other Languages in Indonesia. Tokyo: Research Institute for Languages and Cultures of Asia and Africa.

Schapper, Antoinette (ed.). 2018. Contact and Substrate in the Languages of Wallacea Part 2, vol. 64, NUSA - Linguistic Studies of Indonesian and Other Languages in Indonesia. Tokyo: Research Institute for Languages and Cultures of Asia and Africa.

Silzer, Peter J. 1983. Ambai: An Austronesian Language of Irian Jaya, Indonesia. PhD dissertation, Australian National University.

Slump, F. 1924-38. Grammatica en woordenlijst van de Seroei-Laut taal. Het Utrechts Archief, nummer toegang 2274, inventarisnummer 1102-1.

Spriggs, Matthew. 1995. The Lapita culture and Austronesian prehistory in Oceania. In Peter Bellwood, James J. Fox and Darrell Tryon (eds.), The Austronesians: Historical and Comparative Perspectives, chap. 6, 119-142. Canberra: ANU E Press.

Spriggs, Matthew. 1998. The archaeology of the Bird's Head in its Pacific and Southeast Asian context. Perspectives on the Bird's Head of Irian Jaya, Indonesia, 931-939. Amsterdam: Rodopi.

Stokhof, W.A.L. and Don A.L. Flassy. 1985. A recently discovered M(o)oi vocabulary in the National Museum (Jakarta). In Pacific Linguistics, vol. A-63 (Papers in New Guinea Lingistics 22), 53-130.

Storey, A. A., T. Ladefoged and E. A. Matisoo-Smith. 2008. Counting your chickens: density and distribution of chicken remains in archaeological sites of Oceania. International Journal of Osteoarchaeology 18(3). 240-261. DOI: 10.1002/oa.947.

Storey, Alice A., J. Stephen Athens, David Bryant, Mike Carson, Kitty Emery, Susan deFrance, Charles Higham, Leon Huynen, Michiko Intoh, Sharyn Jones, Patrick V. Kirch, Thegn Ladefoged, Patrick McCoy, Arturo Morales-Muñiz, Daniel Quiroz, Elizabeth Reitz, Judith Robins, Richard Walter and Elizabeth Matisoo-Smith. 2012. Investigating the Global Dispersal of Chickens in Prehistory Using Ancient Mitochondrial DNA Signatures. PLoS ONE 7(7). e39171. DOI: 10.1371/journal.pone.0039171. 
Sutton, Alice, Mary-Jane Mountain, Ken Aplin, Susan Bulmer and Tim Denham. 2009. Archaeozoological records for the highlands of New Guinea: A review of current evidence. Australian Archaeology 69(1). 41-58. DoI: 10.1080/03122417.2009.11681900.

Tadmor, Uri, Martin Haspelmath and Bradley Taylor. 2010. Borrowability and the notion of basic vocabulary. Diachronica 27(2). 226-246. doi: 10.1075/dia.27.2.04tad.

Than, Johanis, Andris Kafiar, Kaleb Waimuri, Spenyel Korwa, Julius Krey, Klemens Rumsarwir and Alfred Rumaropen. 2011. Kamus bahasa daerah Biak. Pemerintah Kabupaten Biak Numfor Dinas Pariwisata dan Kebudayaan.

The Rosetta Project. n.d. Texts. https://archive.org/details/rosettaproject. The Long Now Foundation.

Veth, Peter, Matthew Spriggs, Ako Jatmiko and Susan O'Connor. 1998. Bridging Sunda and Sahul: The archaeological significance of the Aru Islands, southern Moluccas. In Gert-Jan Bartstra (ed.), Bird's Head Approaches, Irian Jaya Studies - A Programme for Interdisciplinary Research, chap. 9, 157-178. Rotterdam: A.A. Balkema.

Visser, Eline. 2016. A Grammar Sketch of Kalamang with a Focus on Phonetics and Phonology. Master's thesis, University of Oslo.

Voorhoeve, C.L. 1975. Languages of Irian Jaya Checklist. Canberra: Pacific Linguistics.

Voorhoeve, C.L. 1982. The West Makian language, north Moluccas, Indonesia: A fieldwork report. In C.L. Voorhoeve (ed.), The Makian languages and their neighbors, 1-74. Canberra: Pacific Linguistics.

Voorhoeve, C.L. 1985. Some notes on the Arandai language. Irian 13. 3-40.

de Vries, Lourens. 1996. Notes on the morphology of the Inanwatan language. In Ger P.

Reesink (ed.), Studies in Irian Languages, vol. 40, NUSA - Linguistic Studies of Indonesian and Other Languages in Indonesia, 97-127. Tokyo: Research Institute for Languages and Cultures of Asia and Africa.

de Vries, Lourens. 200o. Inanwatan. In Ger P. Reesink (ed.), Studies in Irian Languages,

Part II, vol. 47, NUSA - Linguistic Studies of Indonesian and Other Languages in Indonesia, 139-146. Tokyo: Research Institute for Languages and Cultures of Asia and Africa.

de Vries, Lourens. 2002. An introduction to the Inanwatan language of Irian Jaya. In K. Alexander Adelaar and Robert Blust (eds.), Between Worlds: Linguistic Papers in Memory of David John Prentice, 77-94. Canberra: Pacific Linguistics.

de Vries, Lourens. 2004. A Short Grammar of Inanwatan, an Endangered Language of the Bird's Head of Papua, Indonesia. Canberra: Pacific Linguistics.

Wabia, Boas and Emily Gasser. 2019. Mpur Talking Dictionary. Living Tongues Institute for Endangered Languages. http://talkingdictionary.org/mpur.

Whisler, Ronald and Jacqui Whisler. 1995. Sawai introduction and wordlist. In Darrel T. Tryon (ed.), Comparative Austronesian Dictionary: An Introduction to Austronesian Studies. Berlin: Mouton de Gruyter. 
White, J. Peter. 2004. Where the wild things are: Prehistoric animal translocation in the circum New Guinea archipelago. In Scott Fitzpatrick (ed.), Voyages of Discovery: The Archaeology of Islands, 147-164. Westport, CT: Praeger/Greenwood.

Wilson, K.L. and L.A.S. Johnson. 2015. New South Wales flora online: Casuarina equisetifolia. Royal Botanic Gardens and Domain Trust, Sydney.

Wurm, Stephen A, Clemens L Voorhoeve and Kenneth A McElhanon. 1975. The TransNew Guinea phylum in general. New Guinea Area Languages and Language Study 1. 299-322.

Zumbroich, Thomas J. 2008. The origin and diffusion of betel chewing: A synthesis of evidence from South Asia, Southeast Asia and beyond. E-Journal of Indian Medicine $1(3) .87$. 


\section{Appendix I}

Evidence for contact between the various languages of the area is enumerated below. Representative Austronesian forms are listed first, followed by the corresponding Papuan forms; notes on the direction of borrowing (if known) and any other salient information follow.

(4) 'ant/termite': Matbat ili'121 'k.o. ant' :: Moi gili 'termite'.

(5) 'banana': Yerisiam píiti; Umar idi; Warembori uti-ro; Irarutu fud(ə) ${ }^{25}$ :: Maybrat apit; Arandai undi.

From PMP punti. Likely two different loan events, one into Maybrat and another from Irarutu into Arandai.

(6) 'bean': Wamesa kavaru; Roon kavorur; Umar kvaru :: Mpur kaprur; Yawa karavur.

Widespread in coastal CB and Biakic, but no known Austronesian etymology.

(7) 'betel (areca) nut':

a. Irarutu mbwek:: Kalamang buok teun.

b. Ambel fey; Biga gey (Remijsen, 2001) :: Moi dee.

(8) 'betel leaf/pepper (sirih)': Biga utum; Fiawat wotum (Remijsen, 2001) :: Moi kutum.

Betel leaf/pepper and nut are areal trade items, and therefore prime targets for borrowing.

(9) 'bird':

a. Warembori mani-ro; Ambai and Biakic man; Waropen mani; Moor mànu; Irarutu man(ə); Kuri manik; Ambel mani; Gane manik; Sekar manik; etc. :: Arandai maniko; Kalamang maniktapun 'crowned pigeon'; Yawa manok 'bird of paradise'.

Clearly a loan originating in Austronesian, from PMP *manuk. The immediate source into Arandai and Kalamang is most likely a Bomberai language such as Sekar.

b. Kurudu diu :: Tause Weirate $d u$; Tause $n d u$; Maybrat $r u$.

Reconstructed as *du in Proto-Lakes Plain; Clouse (1997) suggests this may be borrowed from Austronesian but given the SHWNG forms this seems unlikely.

(10) 'black': Matbat kabi ${ }^{12} t::$ Arandai ibiti, kibetia.

Origin unknown, possibly Arandai since it is not a known AN etymon.

$25[$ fund(ə)]. 
(11) 'blue/green': Ma'ya mala 3 ; Biga bala (Remijsen, 2001) :: Moi bala 'green'.

(12) '(bread)fruit':

a. Wamesa buo; Ambai; Kurudu; Waropen; and Warembori bo; Moor vó; Kuri avo 'fruit' :: Abun bo (classifier); Inanwatan buqo; Arandai buko; Kembera evuko; Moi wun, Tehit fwon 'fruit'; Ekari po; Mansim wow; Kalamang poi; Hatam mbo; Mansim mwow 'breadfruit'.

The AN forms are reflexes of PMP *buaq. The Ekari word may be related to boku evuko ewuko found in the other Trans-New Guinea languages Arandai and Kemberano. There may be a meaning swap involved, as Kalamang nak 'fruit' resembles the words for 'breadfruit' in several other languages.

b. Wamesa akanak 'breadfruit, cempedak'; Wooi naknak 'breadfruit'; Serui-Laut nakinaki 'jackfruit'; Umar aknak 'cempedak'; Yerisiam náknáà-

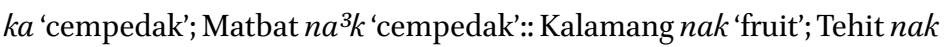
'breadfruit'.

c. Wamesa and Ambai andau '(wild) breadfruit'; Kuri adau 'breadfruit'; Wamesa (Wandamen) and Serui-Laut anda 'mango'; Wooi andang 'mango' :: Tehit ánda 'k.o. seedless breadfruit'; Yawa andau 'breadfruit'.

d. Biak, Meoswar, Roon ur; Yaur úùré; Yerisiam níakáúurú; Umar mur :: Tause uru 'breadfruit'.

This form skips the Yapen languages within Cenderawasih Bay branch of SHWNG; those languages have the more widespread \%nak and \%andau forms, suggesting two borrowing events of \%uru into Biakic and Yaur/Yerisiam/Umar from a Lakes Plains language (likely not landlocked Tause). The Moor form urina may also be part of this complex.

(13) 'cassowary': Pom and Kurudu maswar; Biakic man(u)swar :: Mansim muswar; Abun ndam syor.

The initial syllable $m a(n)$ - comes from the AN word meaning 'bird'; ndam in Abun means 'bird'.

(14) 'cat':

a. Wamesa (Wondama dialect), Pom, Ansus, Meoswar, Roon nau; Umar $n a o$; Yerisiam náò; Matbat ima ${ }^{3} w$ :: Mpur and Moi mau.

Onomatopoetic.

b. Sawai boki (South Halmahera; Whisler and Whisler (1995)) :: Moi boki.

This must have come geographically via Raja Ampat, though no similar forms exist there now.

(15) 'chili pepper': Pom marisan; Biak marisàn; Matbat mare ${ }^{21} s \varepsilon^{3} n$; Ma'ya mare ${ }^{21}$ 'se ${ }^{3} N$ 'peppercorn' :: Yawa marisan Tehit marésan; Moi baisàn. 
This form is present across Yapen and Biakic. It was likely borrowed into Moi and Tehit (or their ancestor) from Raja Ampat, and into Yawa from Yapen or Biakic.

(16) 'cockroach': Wamesa (Wondama dialect) monggasi :: Moi gasi; Tehit ygseT.

(17) 'cuscus': Umar mae; Warembori maya-ro :: Yawa maier; Hatam miei.

(18) 'egg':

a. Ambai neibo; Pom nebuong; Wooi nebuo :: Ekari nipo.

b. Ma'ya; Biga and Kawe tolo (Remijsen, 2001); Ambel tálo :: Moi tolok. From PMP *qatelur.

(19) 'fly': Wamesa amumar; Ansus amoma; Pom amuma; Serui-Laut amandori marea; Kurudu ramat; Warembori namamba-ro :: Yawa amani; Tause Weirate ama .

(20) 'leaf': Wooi raun; Ansus weraung; Waropen rana; Moor rànu :: Kemberano rano; Arandai rono.

From PMP *dahun.

(21) 'owl': Irarutu $u b e^{26}::$ Kalamang kumbai.

(22) 'pig':

a. Biak bén; Meoswar, Roon, Dusner ven; Irarutu f(a)ne; Kuri vene :: Maybrat fane; Seget mon (?).

b. Ma'ya $b o^{3}$; Warembori pue-ro; Umar bue; Waropen fo; Ansus tapui :: Yawa bugwe; Mpur bua.

c. Biga nyok (Remijsen, 2001) :: Abun nok 'wild pig'.

Set (a) probably from PMP *beRay with an added nasal; set (b) certainly so. These resemble the bilabial-heavy TNG forms: Kalamang pep; Mor bia; Arandai and Kemberano poxi; as well as non-TNG Mairasi bembe; Moi baik; Duriankere $b i$; and other Austronesian examples such as Wamesa $p i$ muna and Pom vowa. It would be difficult to claim any causal relationship accounting for all of these forms (c.f. also English pig), but contact is likely involved in some instances. Set (c) is unrelated.

(23) 'rat/mouse': Ambai and Serui-Laut karu; Meoswar karau :: Maybrat kau. These may descend from PCEMP *kazupay, but the correspondence sets are not as well-supported as one might hope.

(24) 'red': Kuri wams; Irarutu wams waməse :: Moi weem.

Geographically somewhat of a stretch, though not totally implausible given historical Raja Ampat/Bomberai connections. The Kuri/Irarutu word, which also means 'blood', is considered by some speakers to be the source of the language name Wamesa.

26 [umbe]. 
(25) 'root': Ma'ya kawat(o) :: Arandai, Kemberano kuato.

(26) 'sago (tree)':

a. Wamesa and Serui-Laut tau; Ambai taun; Irarutu taun :: Arandai towo; Inanwatan otau (k.o. sago); possibly Inanwatan dau and Tehit ndaho 'papeda'.

b. Ma'ya $b i^{3}$; Ambel bey; Umar $a b i$; Waropen $f i$; Yerisiam pi :: Mpur $b i$; Abun bei.

From PMP *Rambia (Kamholz, 2014), greatly (and somewhat irregularly) reduced.

c. Irarutu sagasùgra ${ }^{27}::$ Kalamang sanggeran.

(27) 'sea turtle': Ambel $\phi e n ;$ Ma'ya and Matbat $f e^{3} n$ :: Mpur ven (small variety; likely Hawksbill); Abun fen; Moi mafen.

From PMP *penu.

(28) 'snake': Wamesa koro; Umar kro; Yerisiam gwóorú; also Arguni gor 'snake' (Grace, 1955-56):: Kemberano xore; Awera karuwce.

Most likely a loan into Awera, as other Lakes Plain languages in this sample have cognates of $\phi i$.

(29) 'spider': Irarutu baru28; Umar bravun(?) :: Mpur mamburaw, wambraw.

Irarutu, Umar, and Mpur are fairly widely separated geographically, so this may well be due to chance. However, related forms such as Buli kopolaw and Gebe plaw (Kamholz, 2014) appear in S. Halmahera and Raja Ampat, and may have brought the form to Mpur.

(30) 'taro': Irarutu wagt 29 :: Hatam weng.

One of several Hatam words for different varieties of taro.

(31) 'tree': Yapen ai; Biak $a(i)$; Waropen $a$; Umar ae; Ambel ay; Arguni $a$; As $a$ 'wood; stick' (Greenhill, Blust, and Gray (2008); from Grace) :: Duriankare $a$; Inanwatan áo; Mansim ow.

The AN forms are from PMP kahiw. The fact that this form consists of only one to two phonemes greatly increases the probability of chance resemblance. Duriankere and Inanwatan almost certainly show shared inherited forms with no connection to the AN series. Mansim may be a borrowing from Inanwatan or a third independent innovation; Mansim's only extant relative, Hatam, has pyey.

(32) 'white': Sekar iriris :: Kalamang iriskap.

(33) 'worm': Wamesa kasibui; Ambai kauboi; Roon kasevoi :: Rasawa boi 'worm'; Bauzi boi 'cockroach'.

$\begin{array}{ll}27 & \text { [sə⿹gəsùngrə]. } \\ 28 & \text { [mbaru]. } \\ 29 & \text { [waygt]. }\end{array}$


(34) Ambel kalabet 'goanna' :: Tehit qármbet 'iguana (monitor/goanna?)'; Kalamang kalabet 'earthworm'.

The semantic distance here is not negligible - though perhaps unitable as 'thing that crawls on the ground' - but the segmental correspondence is striking. This transfer may have been facilitated by the presence of a gala sequence in the word for 'worm' in other RA languages (Kawe galatol; Ma'ya agla ${ }^{12} t$; Gebe galawai; etc.) from PMP *kalati. This may indicate the application a 'ground creature' classifier to a 'lizard' root in Ambel, with transfer of only the classifier meaning into Kalamang under influence from Kawe etc. (c.f. Matbat $s a b \varepsilon^{3} t$ 'goanna') and the full meaning into Tehit. Inanwatan marábeto 'iguana (goanna?)' may also be part of this set.

(35) Irarutu akiko 'parrot' :: Arandai ek'ake; Yawa wakikui, Inanwatan qekáqe 'cockatoo'.

Possibly also Wamesa aweko 'cockatoo'. This form may be connected to Proto-TNG *yak 'bird' (c.f. also Kalamang yakop 'cockatoo').

(36) Wamesa, Ansus, Wooi, Serui-Laut aya 'bird' :: Yawa ayak 'cockatoo' :: Hatam hayok; Mansim uyaki 'cockatoo'.

Kamholz (2014) claims that the Yapen form is a reflex of PMP *qayam, though the loss of final *m is somewhat irregular and cognates fail to appear anywhere else SHWNG; reflexes of *manuk are far more widespread. Donohue (1997) claims that the Hatam form is decomposable into /hapyok/ 'bird-put'; this could possibly be extended to Mansim, where the word for bird is waw. If both of these claims are true, then they are unrelated and the Yawa form must be borrowed in from one or the other. In the not-unlikely scenario that either or both claims are false, a Hatam to Yawa to Yapen path might be suggested.

(37) Wamesa musi; Moor vùsi; Waropen wusi 'tree kangaroo' :: Mansim usi 'cuscus'.

(38) Ansus amo 'wallaby, tree kangaroo', amu 'cuscus' :: Sougb uma 'cuscus'.

(39) Yawa mangkawae :: Meoswar manggaye 'bat'; Kuri magaye 'owl'. Not attested elsewhere.

(40) Yawa weran :: Roon veren; Kurudu wen; Biak beren 'betel nut'.

Biakic only, probably a loan from Biak. Limited distribution within Yapen only, possible Yawa source.

(41) Yawa kavambun :: Ambai and Serui-Laut kamambo 'butterfly'.

Likely to have originated in Yawa, as a different cognate set is reflected in surrounding Yapen languages and all other branches of SHWNG (Wamesa apopi, Buli aibobang (Blust, 1978), Ma'ya kala'byobo ${ }^{3} n$, etc. Proto-TNG also has bilabial-heavy *apa(pa)ta. 
(42) Yawa timburu :: Ansus and Umar timburi; Meoswar and Roon timur; Moor timùri; Warembori timori 'cassava'.

Widespread in CB. It has been suggested that this is a loan from the Indonesian word timur 'east', though cassava is called singkong or kasbi in the Malay of the area.

(43) Yawa kangkunam :: Wamesa kakuna 'caterpillar'.

Not attested elsewhere.

(44) Yawa katatim :: Ambai kantanini; Ansus kantating 'cockroach'. Not present elsewhere, likely origin in Yawa.

(45) Yawa angkaijije :: Wooi angkati; Ansus angkadi; Wamesa and Ansus anggadi; Kuri akadi 'coconut'. Yapen only.

(46) Yawa kaumu(r) :: Wamesa kumuar 'dark'. Not attested elsewhere.

(47) Yawa ajo pinam :: Wooi pina maria 'eel'

This may be coincidental. If it is not, the correspondence is interesting as the Wooi form literally means 'thing in the water', and the pina portion potentially borrowed into Yawa is glossed 'thing-LOC'. This same semantic structure is used in the Wondama dialect of Wamesa (venamaria 'RELLOC-water'), Biak (rowar 'thing-water'), and Roon (in vero war 'fish RELLOC water').

(48) Yawa maru :: Moor manù 'forest'.

Kamholz (2014) traces this form to PMP *banua 'inhabited land', though this entails irregular nasalization of the initial *b.

(49) Yawa insumai :: Wamesa samue; Irarutu samwin 'grass'. Also present in Umar.

(50) Yawa keke 'blue' :: Ambai keke; Waropen kakesio 'green; blue'. Yapen and Waropen, possibly Umar (see Section 4.4).

(51) Yawa wao :: Wamesa rau; Serui-Laut re-rau 'leaf'. PMP *dahun.

(52) Yawa andanije :: Wamesa (Wondama dialect) and Serui-Laut anda; Ansus andani; Wooi andang 'mango'. Yapen only. C.f. andau 'breadfruit' in Wamesa (Windesi) and Ambai.

(53) Yawa pikerari :: Ambai fi-karari; Wooi pikarari 'mosquito'. These languages only; likely origin in Yawa.

(54) Yawa koo :: Wooi kou 'owl'

(55) Yawa avone :: Wamesa abo viurar; Ansus awo; Roon avor 'pandanus fruit'. Yapen and Biakic; poorly attested elsewhere.

(56) Yawa anan 'sago, papeda' :: Wooi anang 'sago'; Ambai anan 'papeda'. Found throughout CB, also Biga (Remijsen, 2001) in Raja Ampat. Likely loan into Yawa from AN. 
(57) Yawa kami :: Ansus (ne)kami; Wooi kami ‘seed’. These languages only; likely origin in Yawa.

(58) Yawa tawae :: Wamesa, Ambai, Pom and Serui-Laut tawai ‘snake’. Yapen only.

(59) Yawa aniwan :: Ansus and Pom andiwa; Roon maniver; Moor mananíva 'wasp, bee'.

Found across CB.

(6o) Yawa $b u(g w) a$ :: Ambai, Ansus, and Serui-Laut bua 'white'. Yapen and Raja Ampat. The Yawa form may also connect to Mpur fubwe.

(61) Yawa poper :: Biak pyopr; Waremboori pepera 'white'. Biakic and Warembori; likely origin in Biak.

(62) 'bat, flying fox' Abun (isolate) ndam som (ndam 'bird') :: Mpur som 'sm. bat' :: Moi (West Papuan) sòm.

(63) 'bird of paradise': Kalamang sanggien :: Arandai tiangge.

Both languages are TNG so this may be inherited, but they belong to different primary branches of the family and are geographically not so far from each other, so borrowing seems more probable. This lexeme is poorly attested across the sample, so it may be present in other Bomberai-adjacent varieties as well.

(64) 'butterfly': Ekari (TNG) bobaga :: Moi (W. Papuan) (kam)bawaga. Geographically distant.

(65) 'cat': Tehit (W. Papuan) sika :: Kalamang (TNG) sikan.

(66) 'coconut': Mpur (isolate) tu :: Hatam (Hatam/Mansim) duig :: Moi duu.

(67) 'fly': Mpur bobor :: Mansim kwoboren :: Mairasi (Mairasi) matambura :: Kemberano bora; Arandai bowra; Mor frora (TNG).

(68) 'fruit': Meyah (E. Bird's Head) efek :: Kamoro eke (TNG) :: Maybrat (isolate) ake :: Tunggare (E. Cenderawasih Bay) okia.

(69) 'grass': Meyah mesofou :: Maybrat po-safom.

(70) 'leaf': Bauzi (E. Cenderawasih Bay) ete :: Maybrat ata ita. Resembles Proto-TNG *iti, but neither of these languages belong to that family.

(71) 'louse':

a. Moi sayam :: Mpur (ey)im :: Yawa (isolate) eme :: Mairasi umai :: Meyah mej; Sougb (mougt)mem (E. Bird's Head) :: Hatam mem :: Kamoro (TNG) mamo.

b. Kalamang mun :: Hatam man.

More likely chance, given the geographic separation. The Kalamang form may descend from Proto-TNG *niman.

(72) 'rat':

a. Yawa kaimar :: Mpur kumer.

b. Hatam ncub jop :: Meyah muchup; Sougb ijouhw. 
(73) 'tree':

a. Maybrat ara :: Morwara.

b. Yawa mote :: Kamoro ote; Arandai etamei :: Bauzi ut 'wood'; Tunggare uto-me :: Tause Deirate (Lakes Plain) utakwo.

This resembles the Wamesa word uta 'place, forest' from PMP *qutan - Tunggare uto also means 'forest' - but is unlikely to be related.

(74) 'white': Tunggare pau :: Mansim pow :: Maybrat puh :: Tause Weirate $\phi u$. This may be related to the Raja Ampat forms $b u^{3}(s)$ in Matbat, $b u^{3} s$ in Ma'ya, etc, which are cognate with the words discussed in (61) above.

(75) 'yellow': Hatam $p w k^{30} \sim$ nipug :: Moi pox.

\section{Appendix II: Wordlist}

\section{Colors and related:}

black

blue

brown dark

green

red

\section{Plants:}

banana

bean

betel nut

betel pepper (sirih)

branch

breadfruit

cassava

casuarina tree

chili pepper

coconut flower

forest

fruit

grass

leaf

mango

pandanus fruit

pumpkin/gourd

rice

root sky

white

yellow sago

sago porridge (papeda)

seed

snake

sprout

taro

tree

yam/sweet potato

Animals:

bat

cat

cuscus

bird

chicken

dog

bird of paradise

cockatoo

eel

cassowary

crocodile

egg

30 This is pronounced something like [pфuwk] phonetically, according to Donohue's (1997) phonological rules. 


$\begin{array}{lll}\text { fish } & \text { lizard/gecko } & \text { rat/mouse } \\ \text { frog } & \text { owl } & \text { (sea) turtle } \\ \text { hornbill } & \text { pig } & \text { (tree) kangaroo/wallaby }\end{array}$

Insects and related:

ant

cockroach

mosquito

beetle

fly

butterfly

grasshopper

spider

caterpillar

louse

wasp, bee

worm

\section{Appendix II : Number of Loans per Language}

NB: Though there are 70 items in the word list, some languages here have more than 70 attested forms, as multiple terms for a meaning were collected where available. Languages are divided by family.

\begin{tabular}{llrrl}
\hline Map \# & Language & Total Forms & Loans & Loan Proportion \\
\hline 1 & Ambel: & 48 & 5 & 0.104 \\
2 & Biak: & 65 & 12 & 0.185 \\
3 & Ma'ya: & 39 & 7 & 0.179 \\
4 & Matbat: & 81 & 8 & 0.099 \\
5 & Wamesa: & 80 & 28 & 0.35 \\
6 & Irarutu: & 64 & 14 & 0.219 \\
7 & Kuri: & 41 & 11 & 0.268 \\
8 & Meoswar: & 62 & 13 & 0.21 \\
9 & Roon: & 56 & 13 & 0.232 \\
10 & Dusner: & 8 & 1 & 0.125 \\
11 & Tandia: & 26 & 2 & 0.077 \\
12 & Umar: & 57 & 11 & 0.193 \\
13 & Yaur: & 61 & 5 & 0.082 \\
14 & Yerisiam: & 65 & 10 & 0.154 \\
15 & Waropen: & 39 & 6 & 0.154 \\
16 & Moor: & 65 & 9 & 0.138 \\
17 & Kurudu & 24 & 7 & 0.292 \\
18 & Warembori: & 38 & 23 & 0.184 \\
19 & Ansus: & 81 & 0.284 \\
20 & Wooi: & 50 & 0.4
\end{tabular}




\begin{tabular}{|c|c|c|c|c|}
\hline Map \# & Language & Total Forms & Loans & Loan Proportion \\
\hline 21 & Pom: & 57 & 14 & 0.246 \\
\hline 22 & Serui-Laut: & 42 & 16 & 0.381 \\
\hline 23 & Ambai: & 55 & 24 & 0.436 \\
\hline 24 & Moi: & 97 & 24 & 0.247 \\
\hline 25 & Seget: & 9 & 3 & 0.333 \\
\hline 26 & Tehit: & 93 & 11 & 0.118 \\
\hline 27 & Abun: & 42 & 8 & 0.19 \\
\hline 28 & Mpur: & 90 & 14 & 0.156 \\
\hline 29 & Maybrat: & 36 & 10 & 0.278 \\
\hline 30 & Moskona: & 19 & o & o \\
\hline 31 & Meyah: & $5^{6}$ & 4 & 0.071 \\
\hline 32 & Manikion: & 28 & 1 & 0.036 \\
\hline 33 & Sougb: & 37 & 3 & 0.081 \\
\hline 34 & Hatam: & 64 & 15 & 0.234 \\
\hline 35 & Mansim: & 33 & 13 & 0.394 \\
\hline 36 & Duriankere: & 7 & o & o \\
\hline 37 & Inanwatan: & 67 & 8 & 0.119 \\
\hline 38 & Arandai: & 54 & 15 & 0.278 \\
\hline 39 & Kemberano: & 36 & 5 & 0.139 \\
\hline 40 & Mor: & 18 & 3 & 0.167 \\
\hline 41 & Kalamang: & 57 & 16 & 0.281 \\
\hline 42 & Ekari: & 37 & 5 & 0.135 \\
\hline 43 & Kamoro: & 15 & 3 & 0.2 \\
\hline 44 & Mairasi: & 27 & 2 & 0.074 \\
\hline 45 & Tunggare: & 29 & 5 & 0.172 \\
\hline 46 & Bauzi: & 53 & 5 & 0.094 \\
\hline
\end{tabular}




\begin{tabular}{lllll}
\hline Map \# & Language & Total Forms & Loans & Loan Proportion \\
\hline 47 & Awera: & 25 & 1 & 0.04 \\
48 & Rasawa: & 26 & 1 & 0.038 \\
49 & Tause Deirate: & 23 & 1 & 0.043 \\
50 & Tause Weirate: & 20 & 2 & 0.1 \\
51 & Tause: & 33 & 1 & 0.03 \\
\hline 52 & Yawa: & 85 & 44 & 0.518 \\
\hline
\end{tabular}

